\title{
Endogenous mouse huntingtin is highly abundant in cranial nerve nuclei, co- aggregates to Abeta plaques and is induced in reactive astrocytes in a transgenic mouse model of Alzheimer's disease
}

\author{
Maike Hartlage-Rübsamen ${ }^{1}$, Veronika Ratz ${ }^{1,2}$, Ulrike Zeitschel ${ }^{1}$, Lukas Finzel ${ }^{1}$, Lisa Machner ${ }^{3}$, Janett Köppen³, \\ Anja Schulze ${ }^{3}$, Hans-Ulrich Demuth ${ }^{3}$, Stephan von Hörsten ${ }^{2}$, Corinna Höfling ${ }^{1}$ and Steffen Roßner ${ }^{*^{*}}$ (I)
}

\begin{abstract}
Pathogenic variants of the huntingtin ( $\mathrm{HTT}$ ) protein and their aggregation have been investigated in great detail in brains of Huntington's disease patients and HTT-transgenic animals. However, little is known about the physiological brain region- and cell type-specific HTT expression pattern in wild type mice and a potential recruitment of endogenous HTT to other pathogenic protein aggregates such as amyloid plaques in cross seeding events. Employing a monoclonal anti-HTT antibody directed against the HTT mid-region and using brain tissue of three different mouse strains, we detected prominent immunoreactivity in a number of brain areas, particularly in cholinergic cranial nerve nuclei, while ubiquitous neuronal staining appeared faint. The region-specific distribution of endogenous HTT was found to be comparable in wild type rat and hamster brain. In human amyloid precursor protein transgenic Tg2576 mice with amyloid plaque pathology, similar neuronal HTT expression patterns and a distinct association of HTT with Abeta plaques were revealed by immunohistochemical double labelling. Additionally, the localization of $\mathrm{HTT}$ in reactive astrocytes was demonstrated for the first time in a transgenic Alzheimer's disease animal model. Both, plaque association of HTT and occurrence in astrocytes appeared to be age-dependent. Astrocytic HTT gene and protein expression was confirmed in primary cultures by RT-qPCR and by immunocytochemistry. We provide the first detailed analysis of physiological HTT expression in rodent brain and, under pathological conditions, demonstrate $\mathrm{HTT}$ aggregation in proximity to Abeta plaques and Abeta-induced astrocytic expression of endogenous HTT in Tg2576 mice.
\end{abstract}

Keywords: Huntingtin, Cranial nerve nuclei, Alzheimer's disease, Animal model, Amyloid precursor protein, Astrocytes

\section{Introduction}

Huntingtin (HTT) is a $348 \mathrm{kDa}$ protein mainly known for its pathological role in Huntington's disease (HD). Underlying the autosomal dominantly inherited HD is a pathological increase of CAG repeats in the HTT gene exon 1 that leads to a polyglutamine (polyQ) expansion with $n>39$ in the corresponding protein [47]. Additionally, the protein contains several cleavage sites for caspases and calpains

\footnotetext{
* Correspondence: steffen.rossner@medizin.uni-leipzig.de

${ }^{1}$ Paul Flechsig Institute for Brain Research, University of Leipzig, Leipzig, Germany

Full list of author information is available at the end of the article
}

between amino acids 469 and 586 and fragmentation is suggested to play a significant role in the pathology. As a result, the HTT protein undergoes conformational changes and accumulates in intracellular aggregates $[45,66]$. Clinically, the disease is marked by a progressive loss of motoric and cognitive abilities and the selective death of medium spiny neurons in the striatum with a strong correlation between the length of polyQ and the age of disease onset [29, 84, 85].

Since the HTT polyQ expansion is decisive for HD development, most research so far focused on its pathological role and only little is known about the physiological function of HTT $[9,50]$. The protein is ubiquitously expressed

(c) The Author(s). 2019 Open Access This article is distributed under the terms of the Creative Commons Attribution 4.0 International License (http://creativecommons.org/licenses/by/4.0/), which permits unrestricted use, distribution, and reproduction in any medium, provided you give appropriate credit to the original author(s) and the source, provide a link to the Creative Commons license, and indicate if changes were made. The Creative Commons Public Domain Dedication waiver (http://creativecommons.org/publicdomain/zero/1.0/) applies to the data made available in this article, unless otherwise stated. 
in both rodents and humans with the highest level in the brain [88]. The mouse Htt gene is located on chromosome 5 and shows $86 \%$ homology to the human gene and 91\% homology to the protein sequence. The main difference is reflected by the physiological presence of only six CAG repeats in mice in comparison to the mean length of 20-22 CAGs in unaffected human individuals [2]. Systemically, physiological HTT appears to play a significant role in brain development during embryogenesis, as knock-out mice die at an early embryonic stage [19]. Subcellularly, the physiological form of HTT is mainly localized to the cytoplasm, but some studies report presence of HTT or HTT fragments in the nucleoplasm as well $[4,17,37,64,70]$. However, so far detailed information is neither available on the physiological region-specific expression pattern of endogenous HTT in mouse brain nor on potential interactions of HTT with other pathogenic and aggregation-prone proteins and was therefore investigated in the present study.

Neurodegenerative diseases like HD [45, 66], but also Alzheimer's disease (AD) [26] and Parkinson's disease (PD) [61] share the characteristics of protein misfolding followed by aggregation. Traditionally, basic and clinical research focused on the disease-defining proteins HTT in HD, Abeta and Tau in AD and $\alpha$-synuclein in PD, respectively, to reveal underlying mechanism of pathogenic protein aggregation and its impact on initiation and progression of disease.

However, post mortem examinations of patients revealed co-existence of different misfolded proteins in brain tissue, raising the question whether there might be overlaps and analogies between the specific pathologies $[16,21,31,33]$. Given the fact that proteins can act as homologous seeds [11, 41, 51], the question arose whether seeding could also take place in a heterologous manner. For instance, in vitro and in vivo evidence suggests cross talk between the Abeta peptide and prion protein as well as tau protein $[28,59]$. This scenario, however, is not limited to the co-aggregation of different peptides affected in a particular disease, but also applies to co-aggregation of proteins characteristic for different clinical entities suggesting cross-disease mechanisms of pathogenic protein co-aggregation events.

In particular, the relationship between aggregating peptides typical for AD and PD has been studied before. For example, it was demonstrated that $\alpha$-synuclein can initiate tau aggregation [25]. Additionally, the molecular interrelation of $\alpha$-synuclein with Abeta was investigated, demonstrating specific sites of interaction between membrane-bound $\alpha$-synuclein with Abeta and vice versa [52]. In mutant $\alpha$-synuclein transgenic mice, $\alpha$-synuclein overexpression-induced neurodegeneration led to accumulation of insoluble mouse Abeta [23]. Also, in human PD brain cortical $\alpha$-synuclein load is associated with Abeta plaque burden [45]. In a double transgenic mouse model Abeta was shown to promote $\alpha$-synuclein aggregation and toxic conversion in vivo, suggesting that abnormal interactions between misfolded proteins might contribute to disease pathogenesis [55]. In the brains of patients with $\mathrm{AD} / \mathrm{PD}$ and in transgenic mice, Abeta and $\alpha$-synuclein were shown to co-immunoprecipitate and to form complexes [80]. Additionally, when aspects of $\mathrm{AD}$ and $\mathrm{PD}$ pathologies are combined in transgenic mice, Abeta, tau and $\alpha$-synuclein pathologies are enhanced and cognitive decline is accelerated [12].

In contrast, no information is currently available about the potential cross seeding of Abeta and HTT in AD or HD-associated conditions. Therefore, in order to study a potential influence of Abeta pathology on HTT expression and accumulation we used the transgenic mouse model Tg2576. These mice overexpress human APP695 with the Swedish double mutation KM670/671NL and thereby reproduce the Abeta pathology in an age-dependent manner starting around 11 to 13 months of age [34, 39, 42].

\section{Materials and methods Animals}

The expression of endogenous HTT in brains of 3-month-old wild type animals was analyzed in the inbred mouse lines C57BL/6 $\mathrm{N}(N=3)$ and BALB/c $(N=3)$ and in the outbred line CD1 $(N=3)$ as well as in Wistar rats $(N=$ 3 ) and hamster $(N=1)$. In order to reveal a potential influence of amyloid pathology on endogenous HTT expression in brain, human APP-transgenic Tg2576 mice and wild type littermates at postnatal ages of 15, 18, 24, 28 and 32 months were analyzed. Tg2576 mice are on C57BL/6xSJL background and express human APP695 carrying the Swedish mutation KM670/671NL driven by the hamster prion protein promoter [39]. Founder mice were provided by $\mathrm{K}$. Hsiao-Ashe. Animals were housed at $12 \mathrm{~h}$ day $/ 12 \mathrm{~h}$ night cycles with food and water ad libitum in cages that contained red plastic houses (Tecniplast, Hohenpeißenberg, Germany) and shredded paper flakes to allow nest building. All experimental protocols were approved by Landesdirektion Sachsen, license numbers T11/16 (rat), T14/16 (hamster) and T28/16 (mouse) and all methods were carried out in accordance with the relevant guidelines and regulations.

\section{Immunohistochemistry \\ Tissue preparation}

Mice, rats and hamster were sacrificed by $\mathrm{CO}_{2}$ inhalation and perfused transcardially with $0.9 \%$ saline followed by perfusion with $4 \%$ paraformaldehyde in phosphate buffer (0.1 M, pH 7.4). The brains were removed from the skull and post-fixed by immersion in the same fixative overnight at $4{ }^{\circ} \mathrm{C}$. After cryoprotection in $30 \%$ sucrose in $0.1 \mathrm{M}$ phosphate buffer for three days, horizontal and coronal sections, respectively, of $30 \mu \mathrm{m}$ were cut on a sliding microtome and collected in phosphate buffer with sodium azide. 


\section{Single labelling of HTT}

In order to detect HTT, single labelling immunohistochemistry was performed on free floating brain sections of C57BL/6 N, CD1 and BALB/c mice, Wistar rat and hamster. To allow for a complete mapping of endogenous HTT expression, series of horizontal sections (one in eight) and of coronal sections (one in six) were used for staining. Brain sections were washed in phosphate buffer for $5 \mathrm{~min}$ and endogenous peroxidases were inactivated by treating brain slices with $60 \%$ methanol containing $1 \% \mathrm{H}_{2} \mathrm{O}_{2}$ for 30 min followed by three washing steps with Tris buffered saline (TBS, $0.1 \mathrm{M}, \mathrm{pH}$ 7.4) for 5 min each. After masking unspecific binding sites with blocking solution (5\% normal donkey serum in TBS containing $0.3 \%$ Triton $\mathrm{X}-100$ ) for $30 \mathrm{~min}$ sections were incubated with the primary rabbit monoclonal anti-HTT antibody (EP867Y, raised against HTT amino acids 550650; Abcam). In initial experiments brain sections were incubated with the HTT antibody at dilutions of 1:500, 1:1000, 1:2000 and 1:4000 overnight at $4{ }^{\circ} \mathrm{C}$. Brain sections were washed three times in TBS for 5 min each before being incubated with biotinylated, secondary donkey anti-rabbit antibodies (Dianova; 1:1000) in TBS containing $2 \%$ bovine serum albumin (BSA) for $60 \mathrm{~min}$. After three washing steps in TBS for $5 \mathrm{~min}$ each, slices were incubated with ExtrAvidin peroxidase (Sigma; 1:2000) in TBS/2\% BSA. After washing steps, slices were pre-incubated in Tris buffer $(0.05 \mathrm{M}, \mathrm{pH} 7.6)$ for $5 \mathrm{~min}$ before visualization of peroxidase binding was performed by incubation with $4 \mathrm{mg} \mathrm{3,3}$ '-diaminobenzidine (DAB) and $2.5 \mu \mathrm{H}_{2} \mathrm{O}_{2}$ per $5 \mathrm{ml}$ Tris buffer. After washing, sections were mounted onto glass slides and coverslipped. Based on the results of the different primary antibody dilutions (Additional file 1: Figure S1a) the respective serial stainings were done with a 1:4000 dilution of the primary HTT antibody. The specificity of the EP867Y was validated by the detection of much stronger HTT immunoreactivity in brains of HTT transgenic BACHD mice [30] (Additional file 1: Figure S1b).

\section{Double and triple immunofluorescent labellings}

In order to reveal the brain region- and cell type-specific HTT labelling, the rabbit anti-HTT monoclonal antibody was applied in cocktails with primary antibodies against choline acetyltransferase (ChAT), dopamine and cAMP regulated phosphoprotein $32 \mathrm{kDa}$ (DARPP-32), urocortin-1 (Ucn-1), tyrosine hydroxylase (TH), the astrocyte marker glial fibrillary acidic protein (GFAP) and the microglial marker ionized calcium-binding adapter molecule 1 (Iba-1) as specified in Table 1. In addition, a possible association of HTT with amyloid deposits in APP-transgenic Tg2576 mice was investigated by double labelling of HTT with an antibody directed against Abeta (4G8) and combined with a fluorescent histological stain for fibrillary amyloid (Thioflavin S, ThS), respectively (Table 1). Brain sections were incubated with cocktails of primary antibodies overnight at $4{ }^{\circ} \mathrm{C}$. On the next day, sections were washed three times with TBS and were then incubated with cocktails of Cy2-, Cy3- or Cy5-conjugated donkey anti-mouse, -rabbit or -goat antisera (1:400 each, Dianova) for 60 $\mathrm{min}$ at room temperature. After washing, sections were mounted onto glass slides and coverslipped. ThS staining was performed on mounted sections, by briefly hydrating sections in aqua dest., incubation in ThS (1\%) for $20 \mathrm{~min}$ and differentiation in $80 \%$ ethanol for 20 to $40 \mathrm{~min}$, followed by two rinses in aqua dest., air drying and coverslipping.

For all single and double immunohistochemical labellings in brain sections described above and for immunocytochemistry of primary neuronal and glial cell cultures described below, control experiments in the absence of primary antibodies were carried out. In each case, this resulted in unstained brain sections or primary cells, respectively (not shown). In addition, switching the fluorescent labels of the secondary antibodies (i.e. detection of HTT by secondary donkey anti-rabbit-Cy3 and visualization of ChAT by donkey anti-goat-Cy2) generated similar results to the procedure outlined above (not shown).

\section{Microscopy \\ Light microscopy}

Brain tissue sections of wild type and APP-transgenic $\operatorname{Tg} 2576$ mice immunochemically stained with DAB for HTT expression were examined with an Axio-Scan.Z1 microscope connected with a Colibri.7 light source and an Axiocam 506 camera (Carl Zeiss, Göttingen, Germany). Images of complete brain sections were taken using a 10x objective lens with 0.45 numerical aperture (Zeiss). The ThS counterstaining was revealed in the $488 \mathrm{~nm}$ fluorescence channel of the microscope. Images were digitized by means of ZEN 2.3 software and exported with the NetScope program (Net-Base Software GmbH, Freiburg, Germany) where regions of interest were excised.

\section{Confocal laser scanning microscopy}

Laser scanning microscopy (LSM 510, Zeiss, Oberkochen, Germany) using an Axioplan2 microscope was performed to reveal co-localization of HTT with the neuronal markers ChAT, DARPP-32, TH, Ucn-1, with glial markers GFAP and Iba-1 and with Abeta deposits. For Cy2-labelled antigens (green fluorescence), an argon laser with $488 \mathrm{~nm}$ excitation was used and emission from $\mathrm{Cy} 2$ was recorded at $510 \mathrm{~nm}$ applying a low-range band pass $(505-550 \mathrm{~nm})$. For Cy3-labelled antigens (red fluorescence), a helium-neon-laser with $543 \mathrm{~nm}$ excitation was applied and emission from $\mathrm{Cy} 3$ at $570 \mathrm{~nm}$ was detected applying high-range band pass $(560-615 \mathrm{~nm})$ 
Table 1 Cocktails of antibodies used for double and triple labeling immunohistochemistry

\begin{tabular}{|c|c|c|c|c|}
\hline Primary antibody/stain & Dilution & Host & Company & Secondary antibody \\
\hline HTT (EP867Y) & $1: 1000$ & rabbit & Abcam & donkey anti-rabbit Cy2 \\
\hline ChAT & 1:100 & goat & Millipore & donkey anti-goat Cy3 \\
\hline HTT (EP867Y) & $1: 1000$ & rabbit & Abcam & donkey anti-rabbit Cy2 \\
\hline DARPP-32 & $1: 200$ & guinea pig & Syn. Systems & donkey anti-guinea pig Cy3 \\
\hline HTT (EP867Y) & $1: 1000$ & rabbit & Abcam & donkey anti-rabbit Cy2 \\
\hline Ucn-1 & 1:100 & goat & Santa Cruz & donkey anti-goat Cy3 \\
\hline HTT (EP867Y) & $1: 1000$ & rabbit & Abcam & donkey anti-rabbit Cy2 \\
\hline $\mathrm{TH}$ & $1: 50$ & goat & Santa Cruz & donkey anti-goat Cy3 \\
\hline HTT (EP867Y) & $1: 1000$ & rabbit & Abcam & biotin-donkey anti-rabbit + SA-HRP \\
\hline ThS & $1 \%$ & - & Sigma & - \\
\hline HTT (EP867Y) & $1: 1000$ & rabbit & Abcam & donkey anti-rabbit Cyз \\
\hline Abeta (4G8) & $1: 2000$ & mouse & Biolegend & donkey anti-mouse Cy2 \\
\hline HTT (EP867Y) & $1: 1000$ & rabbit & Abcam & donkey anti-rabbit Cy3 \\
\hline |bal & $1: 200$ & guinea pig & Syn. Systems & donkey anti-mouse Cy5 \\
\hline HTT (EP867Y) & $1: 1000$ & rabbit & Abcam & donkey anti-rabbit Cy3 \\
\hline GFAP (G-A-5) & $1: 1000$ & mouse & Sigma & donkey anti-mouse Cy5 \\
\hline HTT (EP867Y) & $1: 1000$ & rabbit & Abcam & donkey anti-rabbit Cy3 \\
\hline ThS & $1 \%$ & - & Sigma & - \\
\hline GFAP (G-A-5) & $1: 1000$ & mouse & Sigma & donkey anti-mouse Cy5 \\
\hline
\end{tabular}

Secondary antibodies were all from Dianova and used at a dilution of 1:400

$H T T$ huntingtin, ChAT choline acetyltransferase, DARPP-32 dopamine and CAMP regulated phosphoprotein $32 \mathrm{kDa}, U \mathrm{cn}-1 \mathrm{Urocortin}-1, T H$ tyrosine hydroxylase, SAHRP horseradish peroxidase-conjugated streptavidin, Iba1 ionized calcium-binding adapter molecule 1, ThS ThioflavinS, GFAP glial fibrillary acidic protein

and Cy5-labelled antigens (blue fluorescence) were detected using excitation at $650 \mathrm{~nm}$ and emission at 670 $\mathrm{nm}$. Images of areas of interest were taken using a $20 \mathrm{x}$ objective lens with 0.75 numerical aperture (Zeiss). Photoshop CS2 (Adobe Systems, CA) was used to process the images obtained by light and confocal laser scanning microscopy. Care was taken to apply the same brightness, sharpness, color saturation and contrast adjustments in the various pictures.

\section{Huntingtin aggregation assays \\ Expression and purification of huntingtin}

The expression vector pGEX-6P-1 containing exon-1 of HTT and encoding 52 glutamine residues (HTTQ52) was kindly provided by Zoya Ignatova, University of Hamburg, and used to express recombinant HTT for aggregation assays. HTTQ52 with N-terminal GST-tag followed by a polyhistidine tag was expressed in $E$. coli strain BL21 after induction with $400 \mu \mathrm{M}$ IPTG at $24{ }^{\circ} \mathrm{C}$ for $4 \mathrm{~h}$. After harvesting by centrifugation, cells were disrupted by enzymatic lysis and sonification. The first purification step was carried out through $\mathrm{Ni}^{2+}$-chelating chromatography on a Streamline Chelating resin (Streamline Chelating, GE Healthcare Life Sciences). Fractions containing the expression construct were further purified in a second step via a glutathione sepharose resin (Glutathione Sepharose 4FF, GE Healthcare Life Sciences). The removal of glutathione was achieved by dialysis overnight against buffer containing $50 \mathrm{mM}$ Tris/ $\mathrm{HCl}, 150 \mathrm{mM} \mathrm{KCl}, \mathrm{pH} 8.5$. Fractions of interest were lyophilized and stored at $-20^{\circ} \mathrm{C}$ until usage. The purity of the samples was assessed by SDS-PAGE and mass spectrometry. Protein concentrations were determined using UV absorption at $280 \mathrm{~nm}$.

\section{Synthesis of amyloid peptides}

Synthesis and purification of Abeta (1-42) was performed by solid-phase syntheses as described previously [68]. Structures and purities of the Abeta peptide were confirmed by mass spectrometry. The lyophilized peptide 
was dissolved in HFIP (Sigma-Aldrich, St. Louis, USA) overnight. The solvents were evaporated under a stream of nitrogen and Abeta peptides were dissolved in $0.2 \mathrm{M} \mathrm{NaOH}$, followed by buffer and finally titrated with $0.2 \mathrm{M} \mathrm{HCl}$.

\section{ThT fluorescence kinetics assay}

The thioflavin $\mathrm{T}$ (ThT) assay was carried out as described previously [67]. The fibrillation process was induced by cleavage of the GST and polyhistidine tag by PreScission protease (GE Healthcare Life Sciences) and monitored by ThT fluorescence ( $20 \mu \mathrm{M}$, Sigma-Aldrich) at $\lambda$ ex $=440 \mathrm{~nm}$ and $\lambda \mathrm{em}=490 \mathrm{~nm}$ in aggregation buffer (50 mM Tris/HCl, $50 \mathrm{mM} \mathrm{KCl}, 4 \mathrm{mM} \mathrm{MgCl}$, $\mathrm{pH} 8.0$ ) on a FluoStar Optima plate reader (BMG Labtech, Ortenberg, Germany). Signals were recorded at $30^{\circ} \mathrm{C}$ under continuous shaking $(300 \mathrm{rpm})$. Data analysis was done according to [38]. In brief, lag times ( $t_{\text {lag }}$ ) of the aggregation were determined by fitting the straight lines $a$ to the baseline of the lag phase and $b$ as a tangent to the steepest region of the growth phase curve. $\mathrm{T}_{\mathrm{lag}}$ is defined as the time point where the two lines $a$ and $b$ intersect. To obtain the aggregation rate $\mathrm{k}$, the growth phase was fitted to the function: $y=A+B * \exp (-k x)$. Values were obtained from 3 independent determinations and displayed as mean \pm S.D.

\section{Transmission electron microscopy and immunogold labelling}

For immunogold staining the fibril samples $(5 \mu \mathrm{l})$ were fixed on formvar carbon-coated copper grids (Plano, Wetzlar, Germany) with 2\% (w/v) paraformaldehyde (Merck, Darmstadt, Germany) in 0.1 M HEPES buffer (Thermo Fisher, Waltham, USA) for 20 min followed by washing with distilled water. The sections were next incubated for $30 \mathrm{~min}$ at RT with blocking solution (1\% (w/ v) Bovine Serum Album (BSA, Sigma-Aldrich) with 0.1\% Tween-20 (Carl Roth, Karlsruhe, Germany) in $0.1 \mathrm{M}$ HEPES buffer) to prevent unspecific binding. After blocking, the grids were incubated overnight with the primary antibodies directed against HTT (sheep polyclonal, S830, kindly provided by Gillian P. Bates, London, UK; 1:500) and 6E10 (mouse monoclonal, recognizes Abeta (1-42), Merck; 1:250) diluted in blocking solution. After 4 washes of 5 min with blocking solution the grids were incubated for 90 min with secondary antibodies coupled to colloidal gold: anti-sheep IgG $4 \mathrm{~nm}$ gold (donkey polyclonal, Jackson ImmunoResearch, Cambridgeshire, UK) and anti-mouse IgG $20 \mathrm{~nm}$ gold (goat polyclonal, Abcam), 1:20 diluted in blocking solution. After three washing steps with distilled water the grids were negative stained for $5 \mathrm{~min}$ with $2 \%(\mathrm{v} / \mathrm{v})$ uranyl acetate (SERVA Electrophoresis $\mathrm{GmbH}$, Heidelberg, Germany). Transmission electron microscopic images were recorded using a Zeiss EM 912 Omega electron microscope operating at $80 \mathrm{kV}$.

\section{Primary neuronal and astrocytic cultures}

Primary neuronal and astroglial cultures were established from APP-transgenic Tg2576 mice and wild type littermates and grown under standard conditions [35]. Briefly, primary neuronal cell cultures were derived from fetal mouse brain at gestation day 16. Astrocyte-rich primary cell cultures were derived from brains of newborn mice. Cells were grown in 24 well plates on poly-L-lysine-coated coverslips and maintained in DMEM-based medium at $37^{\circ} \mathrm{C}$ in a humidified atmosphere with $95 \%$ air $/ 5 \% \quad \mathrm{CO}_{2}$. The purity of primary cultures was verified by RT-PCR and by immunocytochemistry against neuronal and astrocytic markers (Additional file 1: Figure S2).

\section{RNA isolation and real time quantitative PCR}

A real time quantitative polymerase chain reaction (RT-qPCR) with RNA from primary neurons and astrocytes derived from wild type and $\operatorname{Tg} 2576$ mouse brains, respectively, was performed to analyze cell type-specific HTT expression. RNA of cultivated wild type and Tg2576 neurons and astrocytes was isolated using the Trizol RNA isolation protocol [10]. Quality and concentration of RNA was analyzed with the photometer NanoDrop 2000 at wavelengths $260 \mathrm{~nm}$ and $280 \mathrm{~nm}$. Based on the results obtained from primer testing (Additional file 1: Figure S3a), two primer pairs (\#1 and \#4) were chosen to analyze the HTT expression in cultivated primary astrocytes and neurons. Primer pair \#1 is directed against a region spanning HTT exon 1 and 2, whereas primer pair \#4 recognizes a region located more carboxy-terminally corresponding to the epitope of HTT antibody used in this study. A one-step RT-qPCR was performed to analyze expression of HTT. All working steps were performed on ice and Qiagen RT-PCR Kit was used. RNA of three wild type and three $\mathrm{Tg} 2576$ cell preparations were diluted in RNase free water to obtain a $20 \mathrm{ng} / \mu \mathrm{l} \mathrm{solu}$ tion. All diluted RNA samples were denatured in the Rotor GeneTM 6000 Cycler at $70^{\circ} \mathrm{C}$ for $5 \mathrm{~min}$ to dissolve possible secondary structures and were stored on ice until further usage. Cyclophilin A (CycA) was used as reference gene. Primers for CycA [81] and HTT (50 $\mu \mathrm{M}$ each) were diluted in aqua dest. to obtain a concentration of $10 \mu \mathrm{M}$. Of all samples $0.5 \mu \mathrm{l}$ RNA were added to $9.5 \mu \mathrm{l}$ of master mix and the RT-qPCR was performed with a Rotor GeneTM 6000 Cycler according to Additional file 1: Table S1. Specificity of PCR products was verified by electrophoresis and by analysis of the obtained $\mathrm{C}_{\mathrm{T}}$ values. A detailed analysis of threshold cycle (CT) results obtained with RT-qPCR was performed with the $\Delta \Delta C \mathrm{C}$ method for relative quantification. The linearity of results obtained was validated in a standard curve (Additional file 1: Figure S3b) and PCR control experiments without RT and after DNAse treatment are shown in Additional file 1: Figure S3c. 


\section{Immunocytochemistry}

To determine the cell type-specific expression of endogenous HTT in primary neurons and astrocytes double immunofluorescent labellings of HTT and cell type-specific markers were performed as described for immunohistochemistry on brain sections. Finally, coverslips were air-dried, embedded in entellan/toluene on microscopic slides and stored at $4{ }^{\circ} \mathrm{C}$ in the dark. Additionally, double labelling with neuron- and astrocyte-specific antibodies was performed on neuronal and astroglial primary cultures, to examine the identity and purity of the respective cell cultures.

\section{Results}

\section{Expression of endogenous HTT in wild type mouse brain}

First, the expression of endogenous HTT in C57BL/6 N mouse brain was analyzed by immunohistochemistry. HTT immunoreactivity was present at low levels throughout the brain but was highly enriched in a number of morphologically clearly defined neuronal nuclei. The identities of these nuclei brought out by HTT labelling were determined according to their morphology as well as to their rostro-caudal and dorso-ventral position using a mouse brain atlas [22].

At a high concentration of the primary antibody, a wide-spread HTT immunoreactivity was detected throughout the mouse brain. When diluting the HTT primary antibody from 1:500 to 1:4000, only neuronal populations with highly abundant HTT expression were detected (Additional file 1: Figure S1a). Applying a high HTT antibody dilution to horizontal mouse brain sections, a significant number of neuronal populations in caudal brain regions were still strongly HTT immunoreactive while ubiquitous neuronal staining was abolished (Fig. 1).

The screening of every 6th coronal section identified HTT immunoreactive neurons at different coronal levels. These populations include a distinct subpopulation of striatal neurons, neurons in the basal forebrain including medial septum (MS), vertical and horizontal diagonal band (VDB/HDB), ventral pallidum (VP), olfactory tubercle $(\mathrm{Tu})$, nucleus basalis magnocellularis $(\mathrm{Nbm})$ as well as amygdala (Amy) (Fig. 2). At more caudal coronal brain levels, significant HTT immunoreactivity was detected in Edinger-Westphal nucleus (EWN), pedunculopontine tegmental nucleus (PPT), laterodorsal tegmental nucleus (LDT), motor trigeminal nucleus (Mo5), nucleus abducens (6), nucleus facialis (7) and the perifacial zone (P7), the parvicellular medial vestibular nucleus (MVePC), nucleus ambiguus (Amb), nucleus vagus (10) and the hypoglossal nucleus (12) (Fig. 2).

Interestingly, EP867Y detected HTT immunoreactivity is strongly enriched in cranial nerve nuclei and also significantly present in basal forebrain and in a subset of striatal neurons. In order to validate the identity of the HTT-positive neuronal nuclei and subpopulations, respectively, double labellings with ChAT, Ucn-1, DARPP-32, a marker for medium spiny neurons, and TH were performed. As a result, almost all heavily stained HTT-positive nuclei were found to be cholinergic which was evident by ChAT co-expression. This demonstrates HTT expression by neurons of the respective cranial nerve nuclei and by cholinergic neurons of the basal forebrain (MS, VDB/HDB and $\mathrm{Nbm}$ ) as well as cholinergic interneurons of the striatum (Fig. 2). In contrast, HTT immunoreactivity was absent from DARPP-32-positive striatal medium spiny neurons and from $\mathrm{TH}$-positive locus coeruleus neurons neighboring the LDT (not shown). The only non-cholinergic neuronal population showing high HTT immunoreactivity in mouse brain was the Ucn-1positive neuronal subregion of EWN (Fig. 2). For a general overview, the HTT immunoreactive neuronal populations along the rostro-caudal extension of the brain and their attribution to cranial nerve nuclei are summarized in Table 2 .

Since this is the first detailed analysis of endogenous HTT expression in mouse brain, we considered it important to validate our observations made in the C57BL/ $6 \mathrm{~N}$ strain in brains of two other mouse lines (CD1 and $\mathrm{BALB} / \mathrm{c}$ ). In the brains of these mouse lines very similar HTT expression patterns were observed (not shown). Also in Wistar rat (Fig. 3) and in hamster (Additional file 1: Figure S4) as different rodent species there was an enrichment of HTT immunoreactivity in cranial nerve nuclei and in the cholinergic basal forebrain and caudate putamen structures. A distinct difference to the HTT immunoreactivity in mouse brain, however, was the labelling of neocortical neurons, in particular in layer III pyramidal neurons, CA1 pyramidal neurons and dentate gyrus granule neurons (Fig. 3; Additional file 1: Figure S4), which was not depicted in mouse brain using the same HTT antibody dilution. However, the cortical and hippocampal neurons immunoreactive for HTT in rat brain did not display a distinct cytoplasmic labelling typical for basal forebrain and cranial nerve nuclei, but rather a nuclear HTT localization. The presence of HTT in neuronal nuclei is exemplarily shown for dentate gyrus granule cells (Fig. 3). However, most neuronal populations in basal forebrain and in cranial nerve nuclei displayed cytoplasmic/neuritic labelling (Fig. 3).

\section{HTT expression and aggregation to Abeta plaques in APP-transgenic Tg2576 mice}

At sites of endogenous HTT expression, the formation of cytotoxic HTT aggregates is likely when HTT variants with expanded CAG repeats are expressed. However, in different clinical conditions associated with pathogenic protein aggregation in brain, the formation of protein co-aggregates generated in cross-seeding events is reported.

In order to investigate potential protein cross seeding of endogenous mouse HTT by Abeta aggregates, we analyzed the HTT immunoreactivity in brains of 18-month-old 


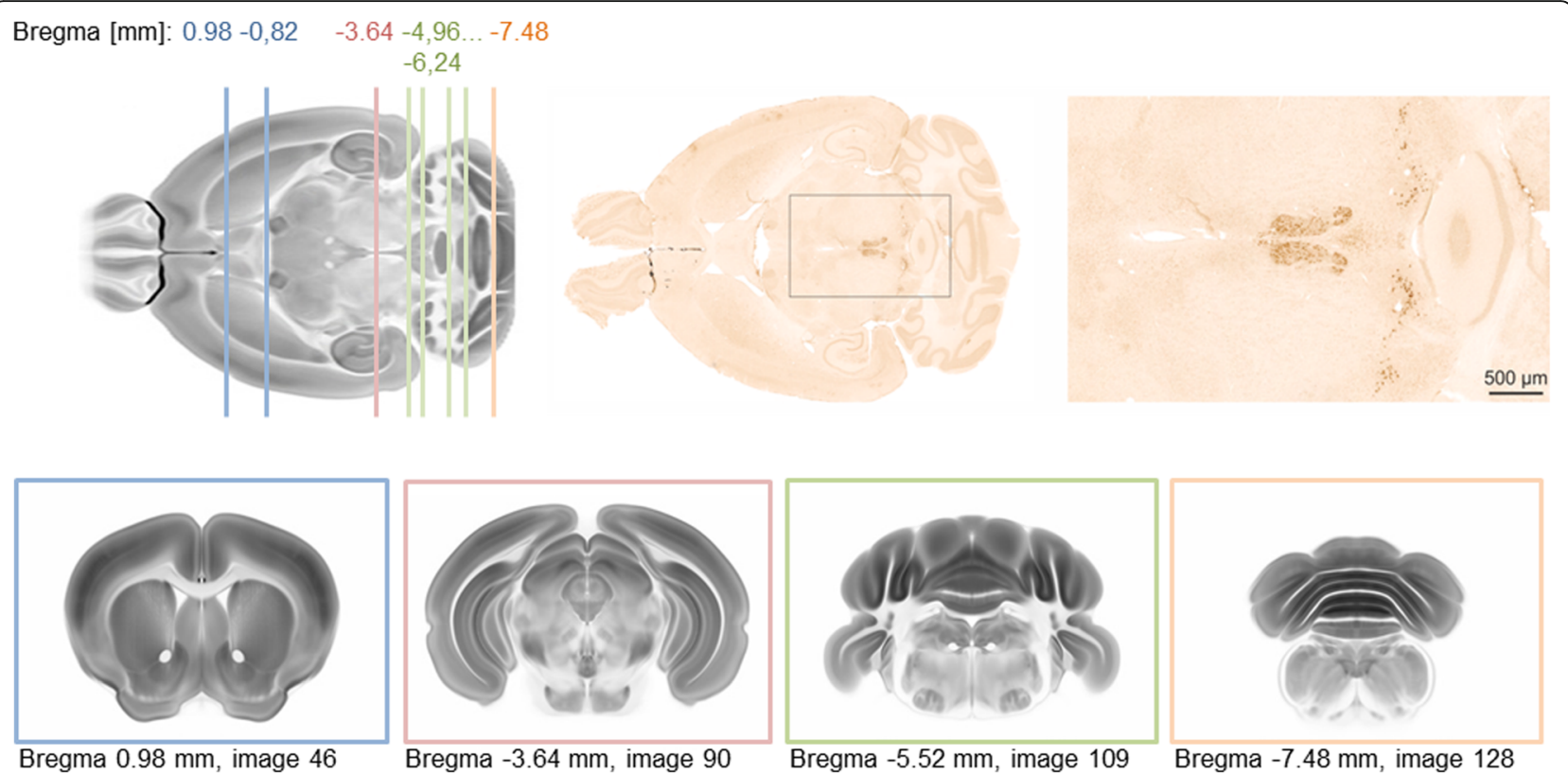

Fig. 1 Immunohistochemistry for huntingtin (HTT) on mouse horizontal brain sections (top, middle and right) and schematic presentation of coronal cutting levels with high abundance of strongly HTT immunoreactive neurons. Note the enrichment of HTT immunoreactivity in caudal brain structures. The anatomical templates used to illustrate cutting levels are shape and signal intensity averages from the Allen Mouse Brain Connectivity Atlas [60]

APP-transgenic Tg2576 mice with amyloid pathology. Basically, the general HTT staining pattern in Tg2576 mouse brain reflected the labelling detected in wild type mice (not shown). However, neocortical and hippocampal HTT immunoreactivity in aged $\operatorname{Tg} 2576$ mice appeared to be additionally associated with amyloid plaque pathology. Therefore, a series of double labellings of HTT with (i) ThS, (ii) the Abeta antibody 4G8 and (iii) the astrocyte marker GFAP were performed and analyzed by confocal laser scanning microscopy (Fig. 4a). These double immunofluorescent stainings demonstrated a punctate HTT immunoreactivity in the near periphery of fibrillary (ThS-positive) and Abeta-immunoreactive extracellular plaques. This labelling pattern was consistently detected irrespective of the brain region (hippocampus and neocortex) and of plaque size. In addition, marked HTT immunoreactivity was detected in amyloid plaque-associated reactive astrocytes (Fig. 4a) but not in microglial cells (not shown). In brains of wild type mice neither punctate nor astrocytic HTT immunoreactivity was observed (Fig. 4a).

In order to reveal whether HTT association with amyloid plaques directly reflects its stimulated aggregation by Abeta peptides, HTT aggregation assays in the absence or presence of $1 \mu \mathrm{M}$ Abeta (1-42) were performed. These assays revealed stimulated HTT aggregation kinetics in the presence of Abeta (Fig. 4b). While the HTT aggregation rate increased significantly in the presence of Abeta peptides, no shortening of the lag phase was observed (Fig. 4b). This indicates that Abeta peptides increase the efficiency of the polymerization event while they do not accelerate the nucleation process. The co-aggregation of HTT with Abeta in fibrils was also demonstrated by transmission electron microscopy (Fig. 4c).

Next, we sought to investigate whether the accumulation of endogenous HTT near Abeta plaques and its induction in reactive astrocytes are age-dependent and increase along with plaque load. Therefore, coronal brain sections of APP-transgenic mice at the postnatal age of $15,18,20,24$ and 32 months, respectively, were used for immunocytochemical triple labelling of HTT, fibrillary Abeta plaques (ThS) and reactive astrocytes (GFAP). We observed an age-dependent increase in hippocampal HTT immunoreactivity, which was paralleled by increases in plaque load and GFAP immunoreactivity (Fig. 5). In negative control experiments without primary antibodies, no labelling for HTT and GFAP was generated (not shown). Additionally, in wild type mice no ThS-positive deposits were detected and HTT and GFAP labellings were comparable to young Tg2576 mice (Fig. 5).

The presence of astrocytic HTT immunoreactivity in hippocampus of $\operatorname{Tg} 2576$ mice is particularly interesting and may result from astrocytic HTT expression and/or uptake of HTT released from neurons. In order to investigate the capability of astrocytes to express HTT, Htt mRNA and HTT protein expression were analyzed by RT-qPCR and by immunocytochemistry in primary mouse neuronal and astrocytic cultures. The purity of neuronal and astrocytic cultures was demonstrated by the detection of the neuronal marker $\mathrm{NeuN}$ and the astrocytic marker 


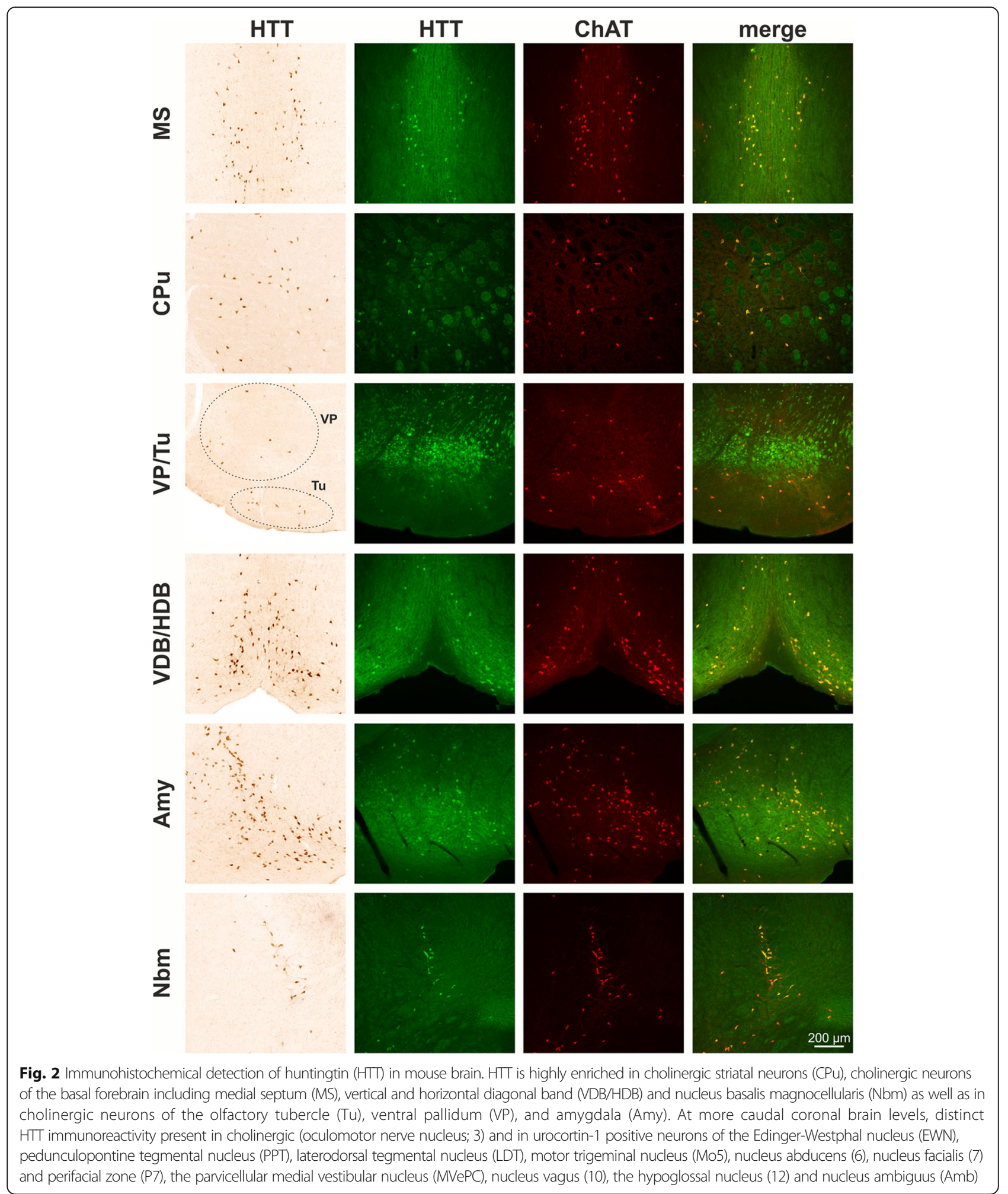

GFAP by RT-PCR and by immunocytochemistry (Additional file 1: Figure S2). These data clearly show the absence of neurons in astrocytic cultures and vice versa.
The analysis of RT-qPCR products by gel electrophoresis demonstrated the expected product size and similar HTT expression levels in primary neurons and astrocytes of both, wild type and $\operatorname{Tg} 2576$ origin (Fig. 6a). $C_{T}$ 


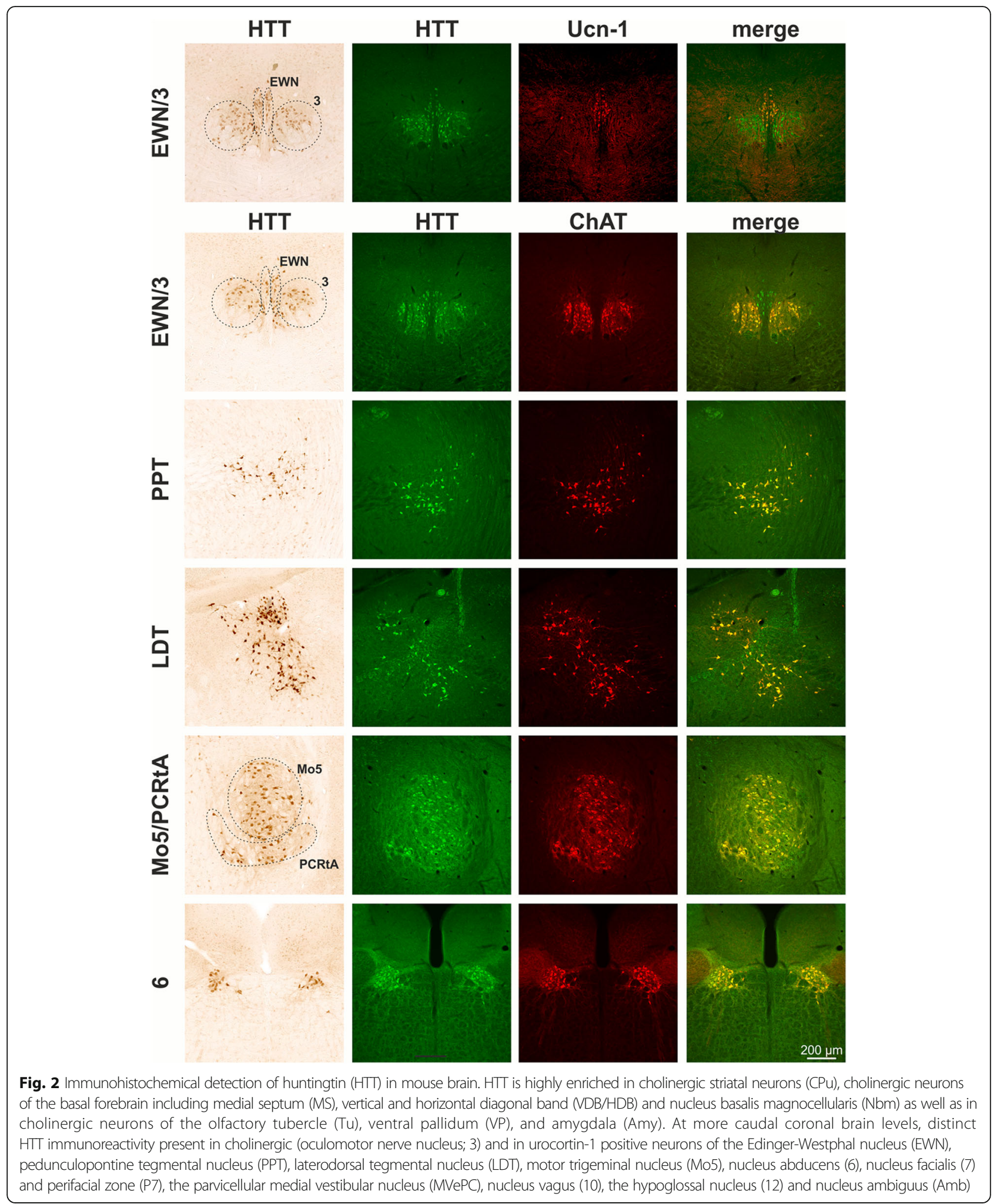

mean values for each cell type, genotype and applied primer pair were calculated and are shown in Table 3 with the corresponding $\Delta C_{T}$ value. The calculated $\Delta C_{T}$ values were further taken to perform relative quantification by comparing the values among each other, obtaining $\Delta \Delta \mathrm{C}_{\mathrm{T}}$. Subsequently, based on $\Delta \Delta C_{\mathrm{T}}$ values, the factor of difference between the two investigated samples was calculated (Table 4). The relative quantification revealed that both 


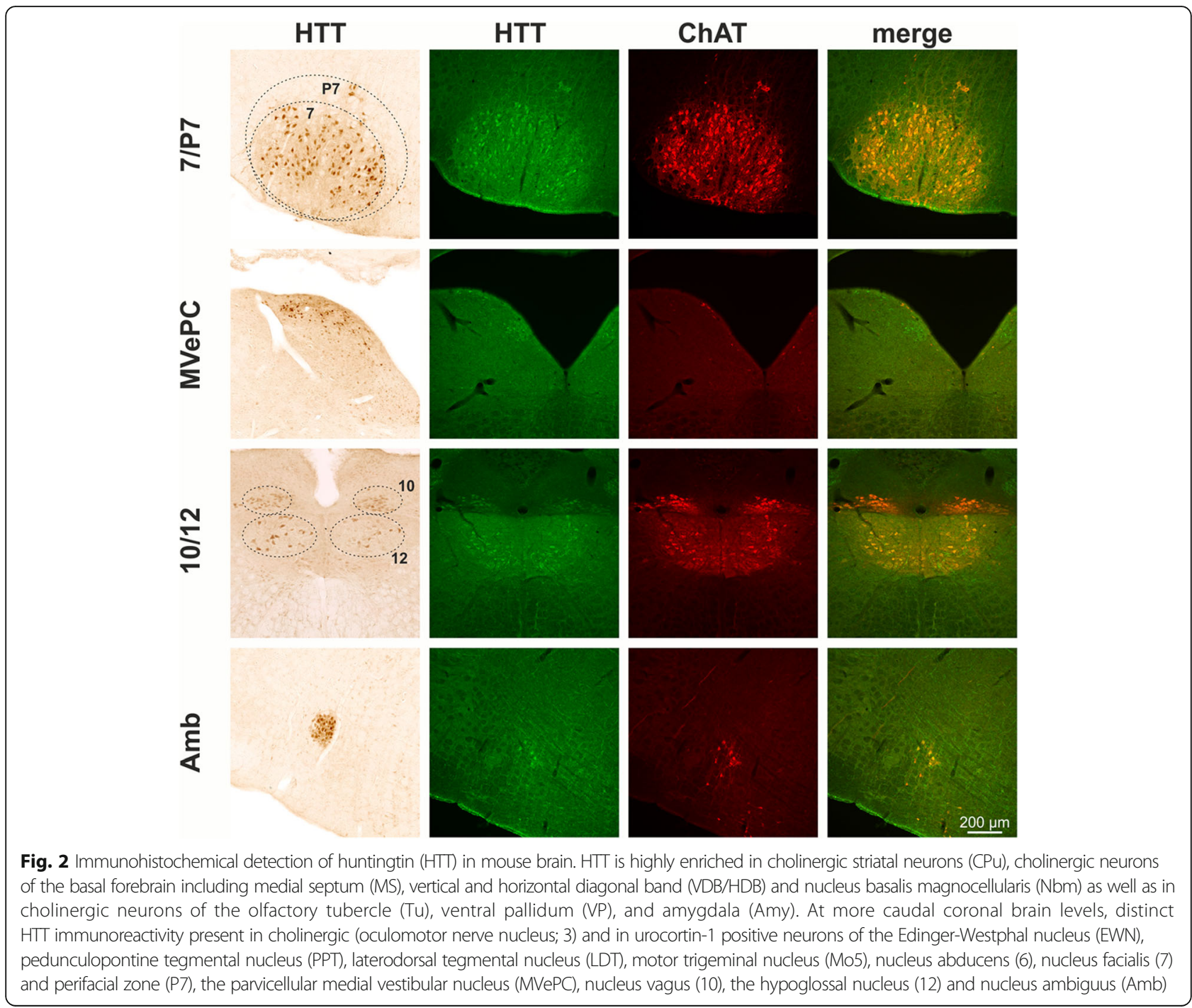

cell types investigated express $\mathrm{Htt}$ mRNA at comparable levels with small fluctuations. In conclusion, by means of Htt RT-qPCR we were able to validate that primary astrocytes of wild type and Tg2576 background do express Htt mRNA in addition to primary neurons.

The data on Htt mRNA expression are supported by immunocytochemical labelling of HTT in mouse primary neurons and astrocytes demonstrating neuronal and astrocytic HTT protein expression (Fig. 6b). Interestingly, primary astrocytes from wild type mice expressed Htt mRNA and HTT protein whereas in brain of adult mice astrocytic HTT immunoreactivity was only observed in transgenic mice and associated with amyloid pathology (Fig. 4).

\section{Discussion}

Expression of endogenous HTT in mouse brain

In HD, the number of CAG repeats of the HTT gene determines the age of disease onset in a fully dominant fashion [47]. When assessing the neuronal populations affected by pathogenic HTT protein aggregation, it is very likely that neurons with abundant HTT expression are more affected than neurons expressing low levels of HTT or no HTT at all. Thus, the defined cellular HTT expression levels might be decisive for the neuron type-specific pathology. From that point of view it is surprising that no detailed analyses on the neuron type-specific endogenous HTT expression patterns in brains of frequently used experimental animal species exist. There is only an early report showing HTT immunoreactivity in the cytoplasm of neurons in rat neocortex and in human cerebellar Purkinje and neocortical neurons as well as neurons of caudate nucleus [17].

Therefore, we here comprehensively analyzed the brain region- and neuron type-specific expression of endogenous HTT in brains of three mouse lines, Wistar rat and hamster using a monoclonal rabbit antibody (EP867Y) 
Table 2 Neuronal populations with highly abundant HTT expression

\begin{tabular}{|c|c|c|c|c|}
\hline \multirow{2}{*}{$\frac{\text { Bregma [mm] }}{+0.98}$} & \multicolumn{2}{|l|}{ structure name } & \multicolumn{2}{|c|}{ Association with cranial nerve nuclei } \\
\hline & MS & medial septum nucleus & & \\
\hline & $\mathrm{CPu}$ & caudate putamen & & \\
\hline & $\mathrm{VP} / \mathrm{Tu}$ & ventral pallidum olfactory tubercle & । & Nervus olfactorius \\
\hline & $\mathrm{VDB} / \mathrm{HDB}$ & nucleus ventral limb diagonal band & & \\
\hline \multirow[t]{2}{*}{-0.82} & Amy & amygdaloid area & & \\
\hline & $\mathrm{Nbm}$ & Nucleus basalis magnocellularis & & \\
\hline \multirow[t]{2}{*}{-3.64} & EWN & Edinger Westphal nucleus & & \\
\hline & 3 & oculomotor nerve nucleus & III & Nervus oculomotorius \\
\hline \multirow[t]{2}{*}{-4.96} & PPT & pedunculopontine tegmental nucleus & & \\
\hline & LDT & laterodorsal tegmental nucleus & & \\
\hline-5.34 & Mo5/PCRtA & motor trigeminal nucleus parvicellular reticular nucleus & & \\
\hline \multirow[t]{2}{*}{-5.80} & 6 & abducens nucleus & $\mathrm{Vl}$ & Nervus abducens \\
\hline & 7/P7 & facial nucleus/perifacial zone & VII & Nervus facialis \\
\hline-6.24 & MVePC & medial vestibular nucleus parvocellular & VIII & Nervus vestibulocochlearis \\
\hline \multirow[t]{3}{*}{-7.48} & 10 & dorsal motor nucleus vagus & $x$ & Nervus vagus \\
\hline & 12 & hypoglossal nucleus & $\mathrm{XII}$ & Nervus hypoglossus \\
\hline & $A m b$ & ambiguus nucleus & & \\
\hline
\end{tabular}

that binds to the HTT mid-region. The specificity of this antibody is validated by Western blot analysis of HTT knock-out cells analyzed along with wild type cells (Product information sheet: https://www.abcam.com/huntingtin-antibody-ep867y-ab45169.html). Furthermore, in the transgenic BACHD HTT mouse model we demonstrate much stronger EP867Y labelling than in wild type mouse brain tissue (Additional file 1: Figure S1b). In addition, the specificity of the EP867Y antibody was demonstrated in a number of recent publications [32, 56, 75].

Interestingly, in the striatum of all mouse lines tested, as well as in rat and hamster, strong HTT immunoreactivity stood out in cholinergic interneurons that are spared in HD [20]. In contrast, in DARPP-32-positive striatal medium-spiny neurons, which are known to be affected in HD [29], significant HTT-labelling with the high threshold selected here was missing. However, also in human brain large striatal neurons that are spared in HD express HTT [64] and deficits in cholinergic markers such as acetylcholinesterase and vesicular acetylcholine transporter without accompanying cell loss have been reported in HD affected subjects $[1,73]$.

We detected ubiquitous low level HTT immunoreactivity throughout the brain but a highly selective enrichment of HTT in cholinergic neurons of the basal forebrain and amygdala, and in particular in cholinergic neurons of cranial nerve nuclei. In addition, prominent HTT expression was revealed in Ucn-1-positive EWN neurons and represented the only non-cholinergic neuronal population with abundant HTT expression identified in the present study. These observations indicate that not only neurons in striatum, but also defined neuronal populations in midbrain and brain stem may be affected by the pathogenic mechanisms resulting from polyQ extension of the HTT protein in HD. Indeed, in HD patients HTT protein inclusions were demonstrated in cranial nerve nuclei III (oculomotor nerve), IV (trochlear nerve), V (trigeminal nerve), VI (abducens nerve), VII (facial nerve), VIII (vestibulocochlear nerve), IX (glossopharyngeal nerve), X (vagal nerve) and XII (hypoglossal nerve) [63]. This is in good accordance with our observation of prominent HTT expression in mouse, rat and hamster brain and would explain some clinical symptoms, (i.e. oculomotor and vestibular deficits) that cannot solely be attributed to degeneration of striatal neurons. Interestingly, HTT-rich vestibular projection neurons predominantly terminate on HTT-negative medium spiny neurons in dorsolateral striatum [78], where significant neurodegeneration in HD occurs. Thus, in addition to local HTT 

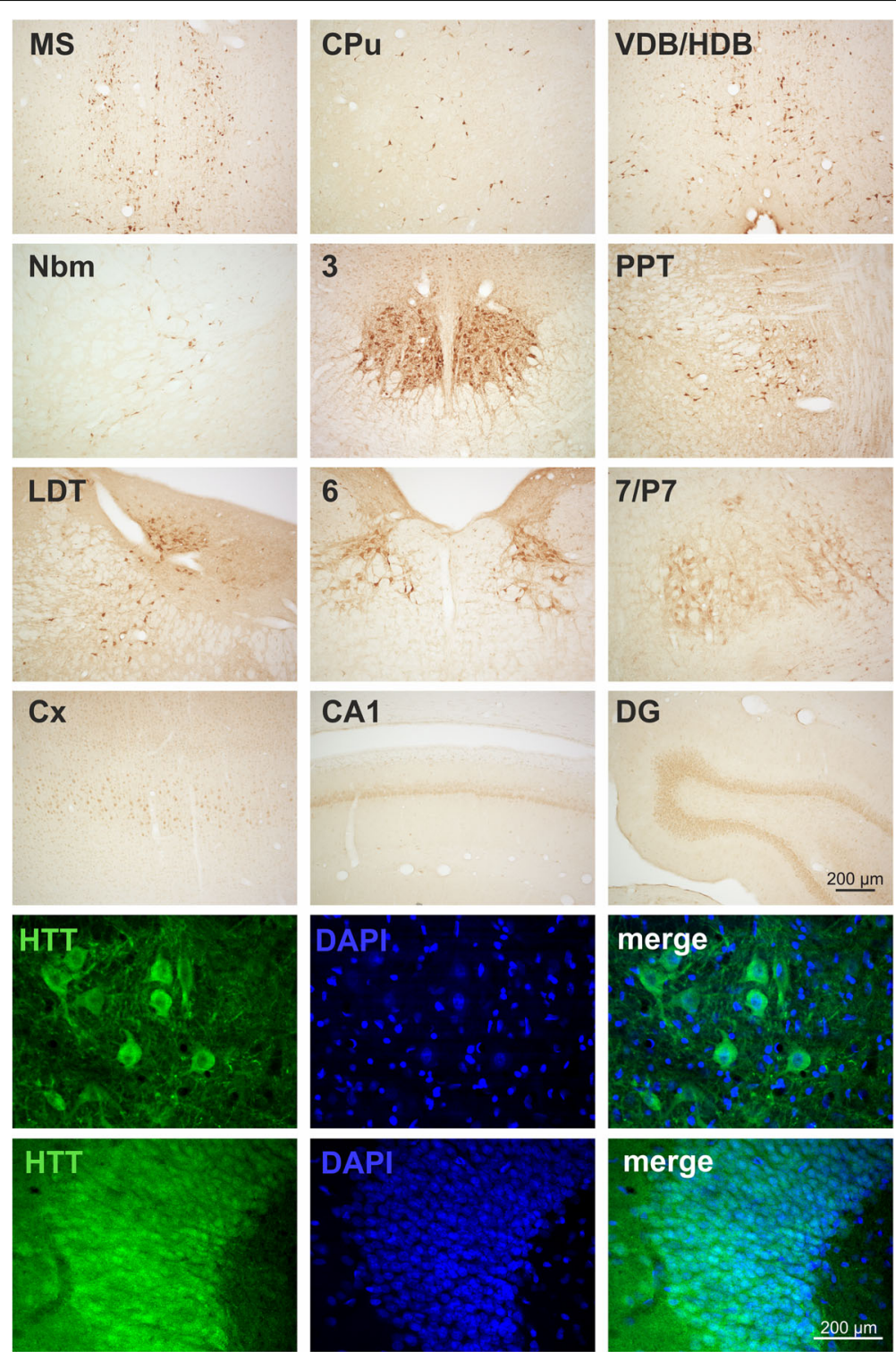

Fig. 3 Immunohistochemical HTT labelling in coronal brain sections of Wistar rat. Note the high abundance of HTT immunoreactivity in medial septum (MS), caudate putamen (CPu), vertical and horizontal diagonal band (VDB/HDB), nucleus basalis magnocellularis (Nbm), oculomotor nerve nucleus (3), pedunculopontine tegmental nucleus (PPT), laterodorsal tegmental nucleus (LDT), nucleus abducens (6), nucleus facialis (7) and perifacial zone (P7). In addition and in contrast to mouse brain, significant HTT immunoreactivity was detected in cortical pyramidal neurons (CX), and in cornu ammonis 1 (CA1) pyramidal and dentate gyrus (DG) granule neurons of the hippocampus

expression, an indirect pathogenic HTT effect in striatum via innervating fibers should be considered based on the evidence presented here.

We would like to note that this pattern of HTT expression was not recapitulated by other HTT antibodies such as $2 \mathrm{~B} 7$ and 2166 . One possible explanation for this is HTT cleavage by different proteases to generate numerous fragments $[44,57]$ and the adoption of different conformational states of the HTT protein $[65,69]$. The epitope of the EP867Y antibody is within amino acids 550 and 650 of HTT and corresponds to residues specific to the apopain (caspase-3) cleavage site [27, 87]. Thus, this antibody appears to be unique and will allow monitoring distinct HTT expression related to cholinergic nuclei.

From the pattern of endogenous HTT expression in mouse, rat and hamster brain, one would predict that under conditions of pathogenic HTT expression the corresponding neuronal functions such as the reward system (VP, CPu, Tu, PPT, Amy), memory processing and decision making (Amy), arousal and attention (PPT), generation of REM sleep (LDT), pupil constriction and eye movement (EWN, oculomotor nerve nucleus, nucleus 
a
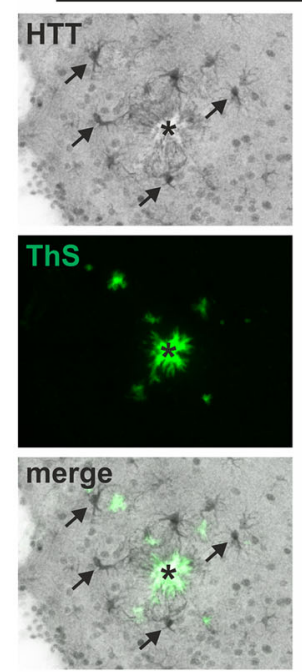

b aggregation kinetics

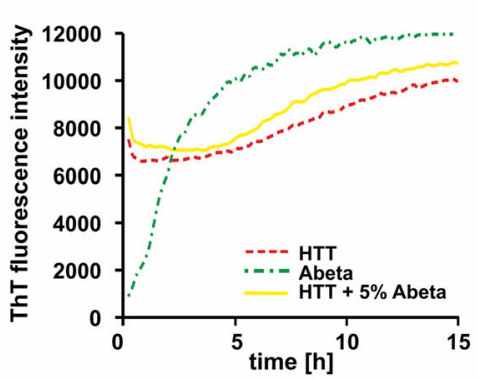

$\operatorname{Tg} 2576$
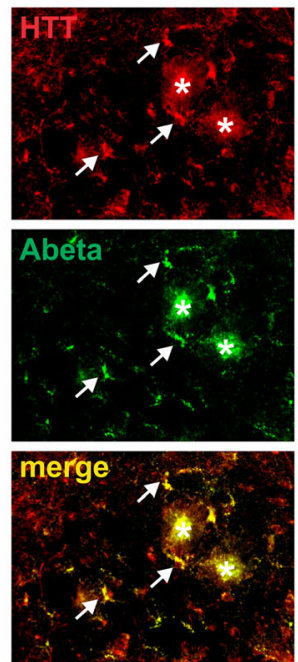
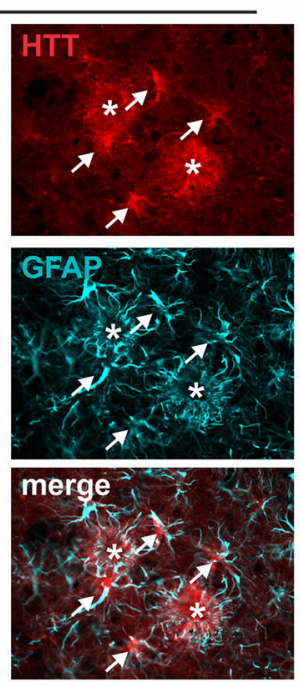

lag phase

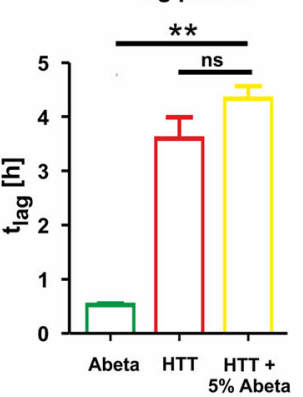

wild type
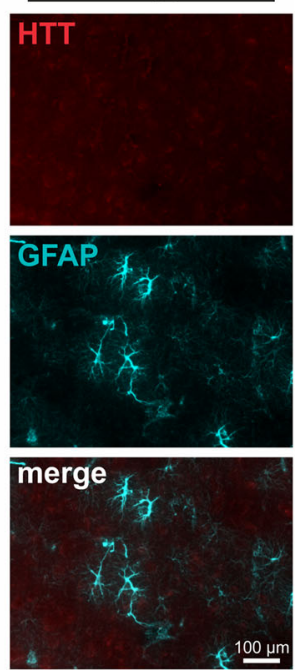

aggregation rate

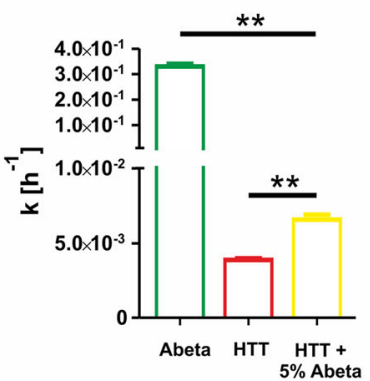

\section{C}
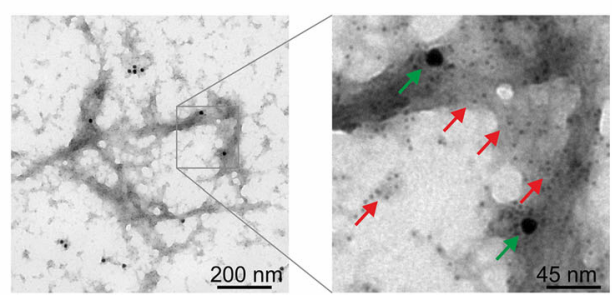

HTT + $5 \%$ Abeta

Abeta

- HTT

Fig. 4 a Association of HTT with Abeta plaques and presence in reactive astrocytes in entorhinal cortex of an 18-month-old Tg2576 mouse. HTT immunoreactivity was found to be present in Abeta plaque-associated glia-like structures (Tg2576 left row, arrows) and aggregate-like structures in the periphery of ThS-positive Abeta plaques (Tg2576 left row, asterisk). This correlation can also be shown using the pan-Abeta-specific antibody $4 \mathrm{G} 8$ (Tg2576 middle row). Double fluorescence labelling of HTT and GFAP demonstrates the presence of HTT in reactive astrocytes (arrows) surrounding Abeta plaques (Tg2576 right row, asterisk). No glial HTT immunoreactivity or aggregate-like structures were detected in age-matched wild type mouse entorhinal cortex (wild type row). b Aggregation of $22.5 \mu \mathrm{M} \mathrm{HTT}$ (red dotted line) and its stimulation by addition of $1 \mu \mathrm{M}$ Abeta (1-42) (yellow solid line) monitored by ThT fluorescence. Note the typical aggregation curve for $1 \mu$ M Abeta (1-42) aggregation alone (green broken line). Statistical analysis revealed an accelerated HTT aggregation rate (right diagram) without effects on the lag phase (middle diagram) after addition of small amounts of Abeta (1-42). c Electron microscopic demonstration of the co-occurrence of HTT (4 nm gold particles) and Abeta (1-42) (20 nm gold particles) after immunogold labelling of fibrils generated from $22.5 \mu \mathrm{M} H \mathrm{HT}$ in the presence of $1 \mu \mathrm{M}$ Abeta (1-42)

abducens), parasympathetic vagal functions (dorsal motor nucleus vagus) and general sensory and motor functions (facial nucleus, Pr5, Mo5, PPT, MVePC, ambiguus nucleus, hypoglossal nucleus) are affected. Indeed, the clinical features of HD such as progressive motor dysfunction, cognitive decline and psychiatric disturbance [86] could be - at least partially - related to dysfunction or death of these neuronal populations. Typical motor dysfunctions in HD include chorea, dystonia, progressive bradykinesia, rigidity and incoordination. In addition, many patients have substantial cognitive or behavioral disturbances before onset of diagnostic motor signs [54]. Interestingly, deep brain 

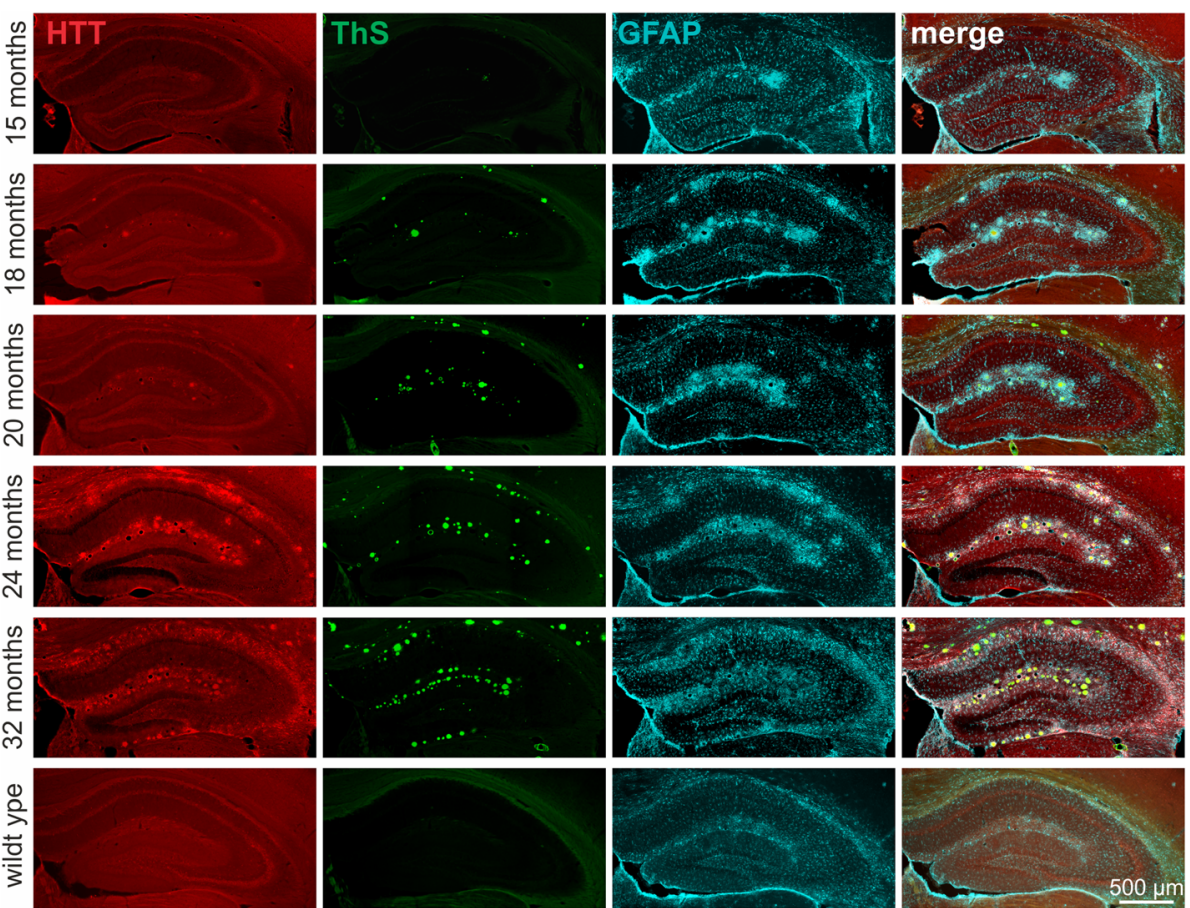

Fig. 5 Triple fluorescent labelling of HTT (red), fibrillary Abeta aggregates (ThS, green) and reactive astrocytes (GFAP, blue) in hippocampus of Tg2576 mice and wild type control. ThS plaque labelling as well as HTT and GFAP immunoreactivity in Tg2576 mice increased in an age-dependent manner

stimulation of the PPT might ameliorate gait and postural difficulties in PD subjects [3, 79]. In addition, a significant cholinergic innervation of the striatum and nucleus accumbens arises from brainstem LDT and PPT nuclei [14]. Thus, when affected during HD pathogenesis, dysfunction and/or degeneration of these neurons may contribute to striatal cholinergic deficits. Indeed, targeting the cholinergic system has been proposed as novel HD therapy [18] and may compensate deficits in numerous cholinergic nerve nuclei with high HTT expression levels. This may also apply to the hypoglossal nerve nucleus which provides innervation of extrinsic and intrinsic muscles of the tongue and, therefore, accounts for the prominent dysphagia and disturbance of speech in HD patients $[48,53,62]$.

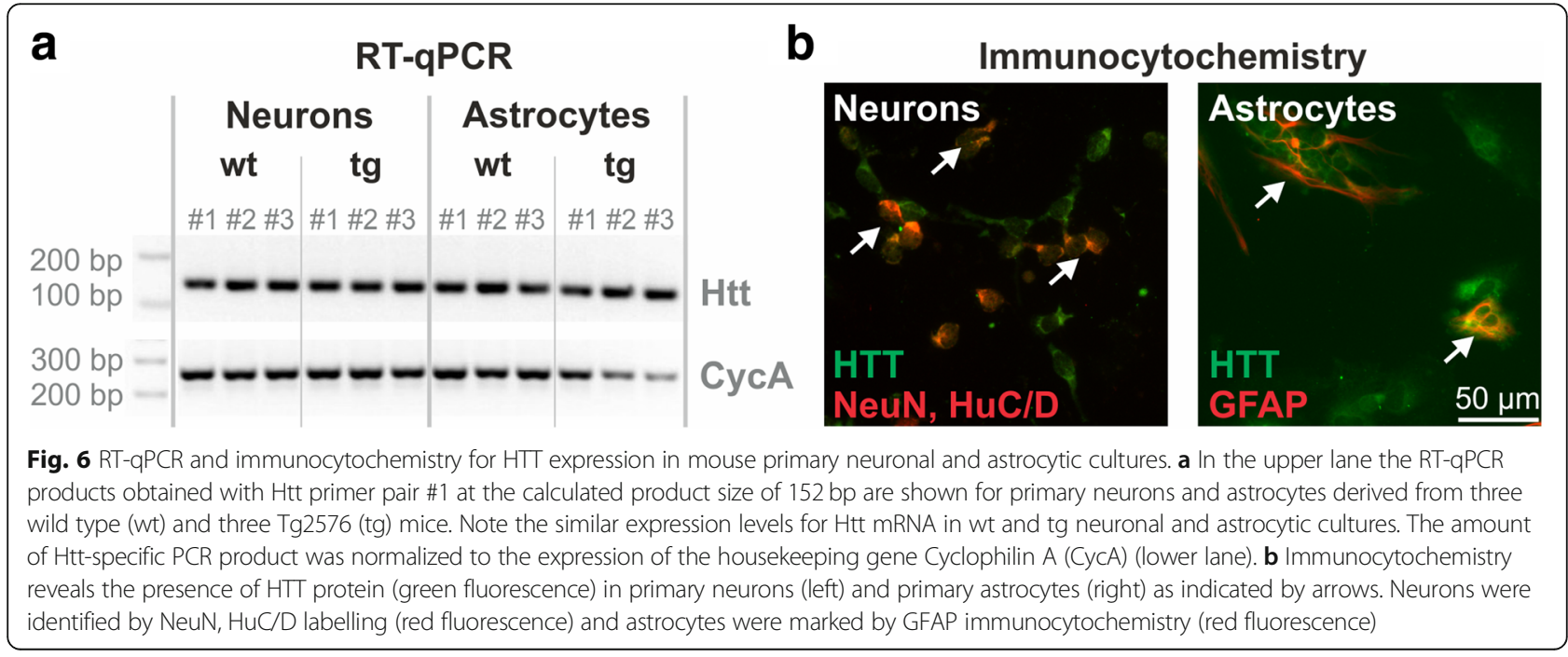


Table 3 Calculated $C_{T}$ means for each sample and primer pair with corresponding $\Delta C_{T}$ value

\begin{tabular}{|c|c|c|c|c|c|}
\hline Sample & $C_{T}$ mean (cyclophilin) & $\mathrm{C}_{\mathrm{T}}$ mean $(\mathrm{Htt} \# 1)$ & $\Delta \mathrm{C}_{\mathrm{T}}(\mathrm{Htt} \# 1)$ & $\mathrm{C}_{\mathrm{T}}$ mean $(\mathrm{Htt} \# 4)$ & $\Delta \mathrm{C}_{\mathrm{T}}(\mathrm{Htt} \# 4)$ \\
\hline Neurons wt & 13.53 & 16.30 & 2.7 & 16.75 & 3.22 \\
\hline Neurons tg & 13.82 & 16.22 & 2.4 & 17.41 & 3.59 \\
\hline Astrocytes wt & 11.98 & 14.88 & 2.90 & 15.80 & 3.82 \\
\hline Astrocytes tg & 12.06 & 15.26 & 3.21 & 16.1 & 4.05 \\
\hline
\end{tabular}

wt wild type, $\operatorname{tg}$ transgenic $\operatorname{Tg} 2576$

\section{Subcellular localization}

Neurons with highly abundant HTT immunoreactivity displayed cytoplasmic localization of HTT. This is consistent with biochemical and electron microscopic analyses which demonstrated the presence of HTT in neuronal cytoplasm and an association with vesicle membrane proteins [17]. In the cytoplasm, full length HTT seems to be particularly involved in intracellular transport processes and vesicle trafficking, as it interacts with microtubules and clathrincoated vesicles [24, 36, 82]. In neurons with lower endogenous HTT expression levels, we also observed faint immunoreactivity in the nucleus. This is in line with reported co-immunoprecipitates with the carboxy-terminal binding protein, known to be a transcriptional co-repressor in the nucleus [43]. An amino-terminal HTT fragment, however, has also been shown to interact with a variety of proteins important for nuclear function, like p53 [77] and nuclear receptor co-repressor protein [5].

\section{Transgenic HD models}

In several transgenic mouse models of HD, mutant HTT is randomly inserted within the genome and its expression is typically driven by neuron-specific promoters other than the endogenous HTT promoter. Most of these mice develop ubiquitinated nuclear HTT inclusions but do not exhibit the full neuropathological phenotype of human HD brains [83]. In particular, brain regions affected by neuronal loss differ from that in HD and the effects on oligodendrocytes and astrocytes in the human brain are not recapitulated in transgenic mice [83]. On the other hand, in knock in mouse models of HD, transgene expression is driven by the endogenous mouse HTT promoter and should lead to pathology in brain regions identified by us as highly HTT expressing. Interestingly, the manifestation of HD-typical pathology including brain atrophy, striatal neuronal loss, severe motor phenotype, weight loss and premature death depends on the expression of N-terminal HTT fragments as present in the R6/2 model expressing exon 1 of the HTT protein under the control of human HTT promoter $[8,49]$. Unfortunately, the more caudal brain regions containing cholinergic cranial nerve nuclei identified by us as strongly immunoreactive for endogenous HTT were not included in the analyses. Thus, we strongly recommend the analyses of these structures and would predict the detection of pathological alterations like HTT protein aggregates and astrogliosis in these clearly defined nuclei.

\section{Protein cross seeding}

An important aspect of the present work was the analyses of a potential HTT protein cross seeding by Abeta aggregates in brains of transgenic mice with amyloid pathology. As the amyloid pathology in the Tg2576 mouse model used is restricted to neocortex and hippocampus, we focused on HTT aggregation in proximity to amyloid plaques in these brain regions. We observed an extracellular halo of HTT immunoreactivity around amyloid plaques labelled with the Abeta-specific antibody 4G8 or by the fibril intercalating dye ThS, respectively. Such protein cross seeding events are known to occur for proteins affected by a particular disease, such as Abeta and tau proteins in AD [28], but also for proteins from different clinical entities such as Abeta and $\alpha$-synuclein proteins affected in $\mathrm{AD}$ and $\mathrm{PD}[23,46,52,55,80]$, respectively. We here demonstrate for the first time that also the endogenous HTT proteins can cross-seed with Abeta aggregates. This process has a clear age-related component and Abeta plaque-associated HTT immunoreactivity in hippocampus increases with plaque load. Since Abeta plaques also contain non-Abeta peptides that could be responsible for HTT recruitment, we directly tested the aggregation of HTT by Abeta (1-42) in ThT aggregation assays. We

Table 4 Comparison of $C_{T}$ means with $\Delta \Delta C_{T}$ method

\begin{tabular}{lllll}
\hline Compared samples & $\Delta \Delta \mathrm{C}_{\mathrm{T}}(\mathrm{Htt} \mathrm{\# 1)}$ & Factor & $\Delta \Delta \mathrm{C}_{\mathrm{T}}(\mathrm{Htt} \# 4)$ & Factor \\
\hline Neurons wt $-\mathrm{tg}$ & -0.387 & 1.30 & 0.37 & 0.78 \\
Astrocytes wt $-\mathrm{tg}$ & 0.30 & 0.81 & 0.23 & 0.85 \\
Neurons wt - astrocytes wt & 0.13 & 0.92 & 0.6 & 0.66 \\
Neurons tg - astrocytes tg & 0.81 & 0.57 & 0.46 & 0.73 \\
\hline
\end{tabular}

wt wild type, $\operatorname{tg}$ transgenic Tg2576 
demonstrate that Abeta peptides increase the efficiency of the polymerization event but have no effect on the nucleation process. The nucleation of polyQ HTT was reported to underlie a different mechanism than nucleation of other amyloid peptides [38]. PolyQ fibrils of HTT do not reveal a typical $\beta$-sheet structure but rather assemble into $\alpha$-helical structures and oligomers which interfere with polyQ sequences and facilitate the formation of amyloid nuclei [58]. A similar effect could occur in the presence of Abeta peptides generating conditions that favor $\beta$-sheet structure and thus result in higher aggregation rates [74]. The biological significance and pathogenic potential of these co-aggregates is not yet clear but they might represent novel therapeutic targets. It has been recently shown in an AD mouse model that targeting one pathogenic protein by passive immunization also attenuates the deposition of other pathogenic protein aggregates, most likely by a mechanism involving activation of the complement system and microglia [13].

Currently, no data are available on cross seeding of HTT to Abeta plaques in AD brains. However, there are several reports analyzing Abeta pathology in HD brains $[15,40,76]$. Based on morphological amyloid and tau staging in autopsy cases of HD, a rare co-existence of $\mathrm{HD}$ and $\mathrm{AD}$ was reported, although initial neuropathological stages of $\mathrm{AD}$ were found to be present early in HD patients [40]. On the other hand, in elderly HD subjects with dementia, a high proportion of subjects displayed tau and amyloid pathology, suggesting that co-occurrence of $\mathrm{AD}$ may contribute to cognitive decline in elderly HD patients [15]. Moreover, a co-occurrence of mixed proteinopathies involving oligomerization and aggregation of Tau, $\alpha$-synuclein and TDP-43 in late stage HD was demonstrated [76], indicating common mechanisms of pathological protein aggregation in different neurodegenerative diseases.

\section{HTT expression by astrocytes}

In brain sections of $\mathrm{Tg} 2576$ mice used for the analyses of HTT protein cross seeding to amyloid plaques we surprisingly observed HTT immunoreactivity in reactive astrocytes in proximity to Abeta plaques. This robust astrocytic HTT immunoreactivity raises the question whether HTT produced by and released from neurons is taken up by astrocytes or whether it is expressed by these glial cells. In order to address this issue, primary neuronal and glial cell cultures from APP-transgenic $\operatorname{Tg} 2576$ mice were established and analyzed for $\mathrm{Htt}$ mRNA and protein expression. Both, primary neurons and astrocytes were shown to express Htt mRNA and protein. This is in agreement with immunohistochemical labellings of brain slices and supportive of de novo synthesis of HTT by astrocytes, rather than uptake of neuron-derived HTT. However, in contrast to the labelling of mouse brain sections, also astrocytes derived from primary cultures of wild type mice expressed HTT indicating that astrocytic HTT expression can generally be induced under conditions of astrocytic activation and independent of Abeta pathology. HTT immunoreactive astrocytes were also detected in the caudate and putamen of HD subjects [72] and in a transgenic HTT mouse model [71]. The intentional and specific mutant HTT expression by astrocytes was demonstrated to cause age-dependent neurological symptoms including body weight loss, motor function deficits, increased susceptibility to glutamate-induced seizures and early death $[6,7]$. Moreover, the mutant HTT expression by cultured primary astrocytes was shown to induce cell death of co-cultured wild type neurons [71]. On the other hand, reduction of astrocytic mutant HTT expression slows disease progression in the BACHD conditional HD mouse model and improves motor and psychiatric-like phenotypes [89]. Thus, there is solid evidence to conclude that astrocytic HTT expression contributes to neurodegeneration in HD.

\section{Conclusions}

We demonstrate a selective enrichment of physiological, endogenous HTT in cranial neve nuclei in mouse, rat and hamster brain. Under clinical conditions of pathogenic HTT variant expression, the functions of these neuronal populations might be compromised. Indeed, clinical symptoms of HD patients not related to dysfunction of striatal medium spiny neurons can be partly attributed to pathogenesis in cranial nerve nuclei. We also demonstrate for the first time an association of endogenous HTT to amyloid plaques and the expression of HTT by reactive astrocytes in a transgenic animal model of AD. These data are in line with cross-disease mechanisms of pathogenic protein co-aggregation present under conditions of $\mathrm{HD}$ and $\mathrm{AD}$.

\section{Additional file}

Additional file 1: Supplementary Information. (PDF 385 kb)

\section{Abbreviations}

AD: Alzheimer's disease; Amb: Ambiguus nucleus; Amy: Amygdala; APP: Amyloid precursor protein; BSA: Bovine serum albumin; ChAT: Choline acetyltransferase; CPu: Caudate putamen; DAB: 3,3'-diaminobenzidine; DARPP-32: Dopamine and CAMP regulated phosphoprotein $32 \mathrm{kDa}$; EWN: Edinger-Westphal nucleus; GFAP: Glial fibrillary acidic protein; HD: Huntington's disease; HDB: Horizontal diagonal band of Broca; HTT: Huntingtin; LC: Locus coeruleus; LDT: Laterodorsal tegmental nucleus; Mo5: Motor trigeminal nucleus; MS: Medial septum; MVePC: Parvicellular medial vestibular nucleus; Nbm: Nucleus basalis magnocellularis; PBS: Phosphate-buffered saline; PCRtA: Parvicellular reticular nucleus; PD: Parkinson's disease; PPT: Pedunculopontine tegmental nucleus; TBS: Trisbuffered saline; TH: Tyrosine hydroxylase; ThS: Thioflavin S; Tu: Olfactory tubercle; Unc-1: Urocortin-1; VDB: Vertical diagonal band of Broca; VP: Ventral pallidum 


\section{Acknowledgements}

We are grateful to Karen Hsiao-Ashe (University of Minnesota) for providing Tg2576 mouse breeders and to Zoya Ignatova (University of Hamburg) for providing the pGEX-6P-1 expression vector containing exon-1 of HTT (HTTQ52). The authors would like to thank Renate Jendrek (Paul Flechsig Institute for Brain Research) for expert technical assistance and Stephan Schilling (Fraunhofer IZI-MWT, Halle/S.) for helpful discussions on study design and interpretation of data. Aspects of this work were supported by the German Federal Department of Education, Science, and Technology, BMBF (grant \#01ED1501A to HUD, grant \#01ED1501B to SR and grant \#01ED1501C to $\mathrm{SvH}$ ) within the European Union Joint Program for Neurodegenerative Disease (JPND) Research, Project CrossSeeds, and by the Alzheimer Forschungsinitiative e.V. (AFI \#16004) to SR. We acknowledge support from the German Research Foundation (DFG) and Leipzig University within the program of Open Access Publishing.

\section{Availability of data and materials}

The datasets used and analyzed during the current study are available from the corresponding author on reasonable request.

\section{Authors' contributions}

MHR designed and supervised the study, performed the histological examination of brain tissue and was a major contributor in writing the manuscript. VR performed immunohistochemical labellings and histological examination of mouse brain tissue. $\mathrm{CH}$ performed the histological examination of mouse, rat and hamster brain tissue and was a major contributor in writing the manuscript. UZ established and analyzed primary mouse neuronal and astrocytic cultures. LF performed immunohistochemical labellings and histological examination of rat and hamster brain tissue. LM and AS expressed and purified HTT and Abeta peptides and performed aggregation assays. JK performed transmission electron microscopy. HUD designed and supervised the study and participated in writing the manuscript. SvH designed and supervised the study, analyzed data and participated in writing the manuscript. SR designed and supervised the study and was a major contributor in writing the manuscript. All authors read and approved the final manuscript.

\section{Ethics approval and consent to participate}

All applicable international, national, and/or institutional guidelines for the care and use of animals were followed. All experiments carried out were in agreement with European regulations on the protection of animals used for scientific purposes (Directive 2010/63/EU), and they were also approved by the Ethical Committee for Animal Research of Landesdirektion Sachsen, license numbers T11/16, T14/16 and T28/16.

\section{Consent for publication}

All the authors have approved publication.

\section{Competing interests}

The authors declare that they have no competing interests.

\section{Publisher's Note}

Springer Nature remains neutral with regard to jurisdictional claims in published maps and institutional affiliations.

\section{Author details}

${ }^{1}$ Paul Flechsig Institute for Brain Research, University of Leipzig, Leipzig, Germany. ${ }^{2}$ Friedrich-Alexander-Universität Erlangen-Nürnberg, Preclinical Experimental Center, Erlangen, Germany. ${ }^{3}$ Fraunhofer Institute for Cell Therapy and Immunology, Department of Molecular Drug Design and Target Validation, Halle (Saale), Germany.

Received: 16 April 2019 Accepted: 17 April 2019

Published online: 20 May 2019

\section{References}

1. Aquilonius SM, Eckernås SA, Sundwall A (1975) Regional distribution of choline acetyltransferase in the human brain: changes in Huntington's chorea. J Neurol Neurosurg Psychiatry 38:669-677
2. Barnes GT, Duyao MP, Ambrose CM, McNeil S, Persichetti F, Srinidhi J, Gusella JF, MacDonald ME (1994) Mouse Huntington's disease gene homolog (Hdh). Somat Cell Mol Genet 20:87-97

3. Benarroch EE (2013) Pedunculopontine nucleus functional organization and clinical implications. Neurology 80:1148-1155

4. Bhide PG, Day M, Sapp E, Schwarz C, Sheth A, Kim J, Young AB, Penney J, Golden J, Aronin N, DiFiglia M (1996) Expression of normal and mutant huntingtin in the developing brain. J Neurosci 16:5523-5535

5. Boutell JM, Thomas P, Neal JW, Weston VJ, Duce J, Harper PS, Jones AL (1999) Aberrant interactions of transcriptional repressor proteins with the Huntington's disease gene product, huntingtin. Hum Mol Genet 8 : 1647-1655

6. Bradford J, Shin JY, Roberts M, Wang CE, Li XJ, Li S (2009) Expression of mutant huntingtin in mouse brain astrocytes causes age-dependent neurological symptoms. Proc Natl Acad Sci U S A 106:22480-22485

7. Bradford J, Shin JY, Roberts M, Wang CE, Sheng G, Li S, Li XJ (2010) Mutant huntingtin in glial cells exacerbates neurological symptoms of Huntington disease mice. J Biol Chem 285:10653-10661

8. Carter RJ, Lione LA, Humby T, Mangiarini L, Mahal A, Bates GP, Dunnett SB, Morton AJ (1999) Characterization of progressive motor deficits in mice transgenic for the human Huntington's disease mutation. J Neurosci 19: 3248-3257

9. Cattaneo E, Zuccato C, Tartari M (2005) Normal huntingtin function: an alternative approach to Huntington's disease. Nat Rev Neurosci 6:919-930

10. Chomczynski P, Mackey K (1995) Short technical reports. Modification of the TRI reagent procedure for isolation of RNA from polysaccharide- and proteoglycan-rich sources. Biotechniques 19:942-945

11. Clavaguera F, Bolmont T, Crowther RA, Abramowski D, Frank S, Probst A, Fraser G, Stalder AK, Beibel M, Staufenbiel M, Jucker M, Goedert M, Tolnay M (2009) Transmission and spreading of tauopathy in transgenic mouse brain. Nat Cell Biol 11:909-913

12. Clinton LK, Blurton-Jones M, Myczek K, Trojanowski JQ, LaFerla FM (2010) Synergistic interactions between $A ß$, tau, and a-synuclein: acceleration of neuropathology and cognitive decline. J Neurosci 30:7281-7289

13. Dai CL, Tung YC, Liu F, Gong CX, lqbal K (2017) Tau passive immunization inhibits not only tau but also AB pathology. Alzheimers Res Ther 9:1

14. Dautan D, Huerta-Ocampo I, Witten IB, Deisseroth K, Bolam JP, Gerdjikov T, MenaSegovia J (2014) A major external source of cholinergic innervation of the striatum and nucleus accumbens originates in the brainstem. J Neurosci 34:4509-4518

15. Davis MY, Keene CD, Jayadev S, Bird T (2014) The co-occurrence of Alzheimer's disease and Huntington's disease: a neuropathological study of 15 elderly Huntington's disease subjects. J Huntingtons Dis 3:209-217

16. Debatin L, Streffer J, Geissen M, Matschke J, Aguzzi A, Glatzel M (2008) Association between deposition of beta-amyloid and pathological prion protein in sporadic Creutzfeldt-Jakob disease. Neurodegener Dis 5:347-354

17. DiFiglia M, Sapp E, Chase K, Schwarz C, Meloni A, Young C, Martin E, Vonsattel JP, Carraway R, Reeves SA, Boyce FM, Aronin N (1995) Huntingtin is a cytoplasmic protein associated with vesicles in human and rat brain neurons. Neuron 14:1075-1081

18. D'Souza GX, Waldvogel HJ (2016) Targeting the cholinergic system to develop a novel therapy for Huntington's disease. J Huntingtons Dis 5:333-342

19. Duyao MP, Auerbach AB, Ryan A, Persichetti F, Barnes GT, McNeil SM, Ge P, Vonsattel JP, Gusella JF, Joyner AL, MacDonald ME (1995) Inactivation of the mouse Huntington's disease gene homolog Hdh. Science 269:407-410

20. Ferrante RJ, Beal MF, Kowall NW, Richardson EP Jr, Martin JB (1987) Sparing of acetylcholinesterase-containing striatal neurons in Huntington's disease. Brain Res 411:162-166

21. Ferrer I, Blanco R, Carmona M, Puig B, Ribera R, Rey MJ, Ribalta T (2001) Prion protein expression in senile plaques in Alzheimer's disease. Acta Neuropathol 101:49-56

22. Franklin KJB, Paxinos G (1997) The mouse brain in stereotaxic coordinates. Academic Press, San Diego ISBN 0-12-266070-6

23. Gallardo G, Schlüter OM, Südhof TC (2008) A molecular pathway of neurodegeneration linking a-synuclein to APOE and Abeta peptides. Nat Neurosci 11:301-308

24. Gauthier LR, Charrin BC, Borrell-Pagès $M$, Dompierre JP, Rangone $H$, Cordelières FP, De Mey J, MacDonald ME, Lessmann V, Humbert S, Saudou F (2004) Huntingtin controls neurotrophic support and survival of neurons by enhancing BDNF vesicular transport along microtubules. Cell 118:127-138

25. Giasson BI, Lee VM, Trojanowski JQ (2003) Interactions of Amyloidogenic proteins. NeuroMolecular Med 4:49-58 
26. Glenner GG, Wong CW (1984) Alzheimer's disease: initial report of the purification and characterization of a novel cerebrovascular amyloid protein. Biochem Biophys Res Commun 120:885-890

27. Goldberg YP, Nicholson DW, Rasper DM, Kalchman MA, Koide HB, Graham RK, Bromm M, Kazemi-Esfarjani P, Thornberry NA, Vaillancourt JP, Hayden MR (1996) Cleavage of huntingtin by apopain, a proapoptotic cysteine protease, is modulated by the polyglutamine tract. Nat Genet 13:442-449

28. Götz J, Chen F, van Dorpe J, Nitsch RM (2001) Formation of neurofibrillary tangles in P301I tau transgenic mice induced by Abeta 42 fibrils. Science 293:1491-1495

29. Graveland GA, Williams RS, DiFiglia M (1985) Evidence for degenerative and regenerative changes in neostriatal spiny neurons in Huntington's disease. Science 227:770-773

30. Gray M, Shirasaki DI, Cepeda C, André VM, Wilburn B, Lu XH, Tao J, Yamazaki I, Li SH, Sun YE, Li XJ, Levine MS, Yang XW (2008) Full-length human mutant huntingtin with a stable polyglutamine repeat can elicit progressive and selective neuropathogenesis in BACHD mice. J Neurosci 28:6182-6195

31. Hainfellner JA, Wanschitz J, Jellinger K, Liberski PP, Gullotta F, Budka H (1998) Coexistence of Alzheimer-type neuropathology in Creutzfeldt-Jakob disease. Acta Neuropathol 96:116-122

32. Hamada K, Terauchi A, Nakamura K, Higo T, Nukina N, Matsumoto N, Hisatsune C, Nakamura T, Mikoshiba K (2014) Aberrant calcium signaling by transglutaminase-mediated posttranslational modification of inositol 1,4,5trisphosphate receptors. Proc Natl Acad Sci U S A 111:E3966-E3975

33. Hamilton RL (2000) Lewy bodies in Alzheimer's disease: a neuropathological review of 145 cases using a-synuclein immunohistochemistry. Brain Pathol 10:378-384

34. Hartlage-Rübsamen M, Morawski M, Waniek A, Jäger C, Zeitschel U, Koch B, Cynis H, Schilling S, Schliebs R, Demuth HU, Roßner S (2011) Glutaminyl cyclase contributes to the formation of focal and diffuse pyroglutamate (pGlu)-Aß deposits in hippocampus via distinct cellular mechanisms. Acta Neuropathol 121:705-719

35. Hartlage-Rübsamen $M$, Waniek $A$, Meissner J, Morawski M, Schilling $S$, Jäger C, Kleinschmidt M, Cynis H, Kehlen A, Arendt T, Demuth HU, Roßner S (2015) Isoglutaminyl cyclase contributes to CCL2-driven neuroinflammation in Alzheimer's disease. Acta Neuropathol 129:565-583

36. Hoffner G, Kahlem P, Djian P (2002) Perinuclear localization of huntingtin as a consequence of its binding to microtubules through an interaction with betatubulin: relevance to Huntington's disease. J Cell Sci 115:941-948

37. Hoogeveen AT, Willemsen R, Meyer N, de Rooij KE, Roos RA, van Ommen GJ, Galjaard H (1993) Characterization and localization of the Huntington disease gene product. Hum Mol Genet 2:2069-2073

38. Hortschansky P, Schroeckh V, Christopeit T, Zandomeneghi G, Fändrich M (2005) The aggregation kinetics of Alzheimer's beta-amyloid peptide is controlled by stochastic nucleation. Protein Sci 14:1753-1759

39. Hsiao K, Chapman P, Nilsen S, Eckman C, Harigaya Y, Younkin S, Yang F, Cole G (1996) Correlative memory deficits, Abeta elevation, and amyloid plaques in transgenic mice. Science 274:99-102

40. Jellinger KA (1998) Alzheimer-type lesions in Huntington's disease. J Neural Transm 105:787-799

41. Kane MD, Lipinski WJ, Callahan MJ, Bian F, Durham RA, Schwarz RD, Roher AE, Walker LC (2000) Evidence for seeding of beta-amyloid by intracerebra infusion of Alzheimer brain extracts in beta-amyloid precursor proteintransgenic mice. J Neurosci 20:3606-3611

42. Kawarabayashi T, Younkin LH, Saido TC, Shoji M, Ashe KH, Younkin SG (2001) Age-dependent changes in brain, CSF, and plasma amyloid (beta) protein in the Tg2576 transgenic mouse model of Alzheimer's disease. J Neurosci 21:372-381

43. Kegel KB, Meloni AR, Yi Y, Kim YJ, Doyle E, Cuiffo BG, Sapp E, Wang Y, Qin ZH, Chen JD, Nevins JR, Aronin N, DiFiglia M (2002) Huntingtin is present in the nucleus, interacts with the transcriptional corepressor C-terminal binding protein, and represses transcription. J Biol Chem 277:7466-7476

44. Kim YJ, Yi Y, Sapp E, Wang Y, Cuiffo B, Kegel KB, Qin ZH, Aronin N, DiFiglia M (2001) Caspase 3-cleaved $\mathrm{N}$-terminal fragments of wild-type and mutant huntingtin are present in normal and Huntington's disease brains, associate with membranes, and undergo calpain-dependent proteolysis. Proc Natl Acad Sci U S A 98:12784-12789

45. Landles C, Sathasivam K, Weiss A, Woodman B, Moffitt H, Finkbeiner S, Sun B, Gafni J, Ellerby LM, Trottier Y, Richards WG, Osmand A, Paganetti P, Bates GP (2010) Proteolysis of mutant huntingtin produces an exon 1 fragment that accumulates as an aggregated protein in neuronal nuclei in Huntington disease. J Biol Chem 285:8808-8823
46. Lashley T, Holton JL, Gray E, Kirkham K, O'Sullivan SS, Hilbig A, Wood NW, Lees AJ, Revesz T (2008) Cortical alpha-synuclein load is associated with amyloid-beta plaque burden in a subset of Parkinson's disease patients. Acta Neuropathol 115:417-425

47. Lee JM, Ramos EM, Lee JH, Gillis T, Mysore JS, Hayden MR, Warby SC, Morrison P, Nance M, Ross CA, Margolis RL, Squitieri F, Orobello S, Di Donato S, Gomez-Tortosa E, Ayuso C, Suchowersky O, Trent RJ, McCusker E, Novelletto A, Frontali M, Jones R, Ashizawa T, Frank S, Saint-Hilaire MH, Hersch SM, Rosas HD, Lucente D, Harrison MB, Zanko A, Abramson RK, Marder K, Sequeiros J, Paulsen JS, PREDICT-HD study of the Huntington Study Group (HSG), Landwehrmeyer GB; REGISTRY study of the European Huntington's Disease Network, Myers RH; HD-MAPS Study Group, MacDonald ME, Gusella JF; COHORT study of the HSG (2012) CAG repeat expansion in Huntington disease determines age at onset in a fully dominant fashion. Neurology 78:690-695

48. Leopold NA, Kagel MC (1985) Dysphagia in Huntington's disease. Arch Neurol 42:57-60

49. Li H, Li SH, Johnston H, Shelbourne PF, Li XJ (2000) Amino-terminal fragments of mutant huntingtin show selective accumulation in striatal neurons and synaptic toxicity. Nat Genet 25:385-389

50. Lin CH, Tallaksen-Greene S, Chien WM, Cearley JA, Jackson WS, Crouse AB, Ren S, Li XJ, Albin RL, Detloff PJ (2001) Neurological abnormalities in a knock-in mouse model of Huntington's disease. Hum Mol Genet 10:137-144

51. Luk KC, Song C, O'Brien P, Stieber A, Branch JR, Brunden KR, Trojanowski JQ, Lee VM (2009) Exogenous alpha-synuclein fibrils seed the formation of Lewy body-like intracellular inclusions in cultured cells. Proc Natl Acad Sci U S A 106:20051-20056

52. Mandal PK, Pettegrew JW, Masliah E, Hamilton RL, Mandal R (2006) Interaction between Abeta peptide and a-synuclein: molecular mechanisms in overlapping pathology of Alzheimer's and Parkinson's in dementia with Lewy bodies. Neurochem Res 31:1153-1162

53. Manor Y, Oestreicher-Kedem Y, Gad A, Zitser J, Faust-Socher A, Shpunt D, Naor S, Inbar N, Kestenbaum M, Giladi N, Gurevich T (2018) Dysphagia characteristics in Huntington's disease patients: insights from the fiberoptic endoscopic evaluation of swallowing and the swallowing disturbances questionnaire. CNS Spectr 10:1-6

54. Marder K, Zhao H, Myers RH, Cudkowicz M, Kayson E, Kieburtz K, Orme C, Paulsen J, Penney JB Jr, Siemers E, Shoulson I (2000) Rate of functional decline in Huntington's disease. Huntington Study Group. Neurology 54:452-458

55. Masliah E, Rockenstein E, Veinbergs I, Sagara Y, Mallory M, Hashimoto M, Mucke $L$ (2001) $\beta$-Amyloid peptides enhance a-synuclein accumulation and neuronal deficits in a transgenic mouse model linking Alzheimer's disease and Parkinson's disease. Proc Natl Acad Sci U S A 98:12245-12250

56. Massai L, Petricca L, Magnoni L, Rovetini L, Haider S, Andre R, Tabrizi SJ, Süssmuth SD, Landwehrmeyer BG, Caricasole A, Pollio G, Bernocco S (2013) Development of an ELISA assay for the quantification of soluble huntingtin in human blood cells. BMC Biochem 14:34

57. Mende-Mueller LM, Toneff T, Hwang SR, Chesselet MF, Hook WY (2001) Tissue-specific proteolysis of huntingtin (htt) in human brain: evidence of enhanced levels of $\mathrm{N}$ - and C-terminal htt fragments in Huntington's disease striatum. J Neurosci 2:1830-1837

58. Mishra R, Jayaraman M, Roland BP, Landrum E, Fullam T, Kodali R, Thakur AK, Arduini I, Wetzel R (2012) Inhibiting the nucleation of amyloid structure in a huntingtin fragment by targeting a-helix-rich oligomeric intermediates. J Mol Biol 415:900-917

59. Morales R, Estrada LD, Diaz-Espinoza R, Morales-Scheihing D, Jara MC, Castilla J, Soto C (2010) Molecular cross talk between misfolded proteins in animal models of Alzheimer's and prion diseases. J Neurosci 30:4528-4535

60. Oh SW, Harris JA, Ng L, Winslow B, Cain N, Mihalas S, Wang Q, Lau C, Kuan L, Henry AM, Mortrud MT, Ouellette B, Nguyen TN, Sorensen SA, Slaughterbeck CR, Wakeman W, Li Y, Feng D, Ho A, Nicholas E, Hirokawa KE, Bohn P, Joines KM, Peng H, Hawrylycz MJ, Phillips JW, Hohmann JG, Wohnoutka P, Gerfen CR, Koch C, Bernard A, Dang C, Jones AR, Zeng H (2014) A mesoscale connectome of the mouse brain. Nature 508:207-214

61. Recchia A, Debetto P, Negro A, Guidolin D, Skaper SD, Giusti P (2004) Alphasynuclein and Parkinson's disease. FASEB J 18:617-626

62. Reilmann R, Bohlen S, Klopstock T, Bender A, Weindl A, Saemann P, Auer DP, Ringelstein EB, Lange HW (2010) Tongue force analysis assesses motor phenotype in premanifest and symptomatic Huntington's disease. Mov Disord 25:2195-2202

63. Rüb U, Hentschel M, Stratmann K, Brunt E, Heinsen H, Seidel K, Bouzrou M, Auburger G, Paulson H, Vonsattel JP, Lange H, Korf HW, den Dunnen W 
(2014) Huntington's disease (HD): degeneration of select nuclei, widespread occurrence of neuronal nuclear and axonal inclusions in the brainstem. Brain Pathol 24:247-260

64. Sapp E, Schwarz C, Chase K, Bhide PG, Young AB, Penney J, Vonsattel JP, Aronin N, DiFiglia M (1997) Huntingtin localization in brains of normal and Huntington's disease patients. Ann Neurol 42:604-612

65. Saudou F, Humbert S (2016) The biology of huntingtin. Neuron 89:910-926

66. Schilling G, Klevytska A, Tebbenkamp AT, Juenemann K, Cooper J, Gonzales V, Slunt H, Poirer M, Ross CA, Borchelt DR (2007) Characterization of huntingtin pathologic fragments in human Huntington disease, transgenic mice, and cell models. J Neuropathol Exp Neurol 66:313-320

67. Schlenzig D, Manhart S, Cinar Y, Kleinschmidt M, Hause G, Willbold D, Funke SA, Schilling S, Demuth HU (2009) Pyroglutamate formation influences solubility and amyloidogenicity of amyloid peptides. Biochemistry 48:7072-7078

68. Schlenzig D, Rönicke R, Cynis H, Ludwig HH, Scheel E, Reymann K, Saido T, Hause G, Schilling S, Demuth HU (2012) N-terminal pyroglutamate formation of $A \beta 38$ and $A \beta 40$ enforces oligomer formation and potency to disrupt hippocampal long-term potentiation. J Neurochem 121:774-784

69. Seong IS, Woda JM, Song JJ, Lloret A, Abeyrathne PD, Woo CJ, Gregory G, Lee JM, Wheeler VC, Walz T, Kingston RE, Gusella JF, Conlon RA, MacDonald ME (2010) Huntingtin facilitates polycomb repressive complex 2. Hum Mol Genet 19:573-583

70. Sharp AH, Loev SJ, Schilling G, Li SH, Li XJ, Bao J, Wagster MV, Kotzuk JA, Steiner JP, Lo A, Hedreen J, Sisodia S, Snyder SH, Dawson TM, Ryugo DK, Ross CA (1995) Widespread expression of Huntington's disease gene (IT15) protein product. Neuron 14:1065-1074

71. Shin JY, Fang ZH, Yu ZX, Wang CE, Li SH, Li XJ (2005) Expression of mutant huntingtin in glial cells contributes to neuronal excitotoxicity. J Cell Biol 171 1001-1012

72. Singhrao SK, Thomas P, Wood JD, MacMillan JC, Neal JW, Harper PS, Jones AL (1998) Huntingtin protein colocalizes with lesions of neurodegenerative diseases: an investigation in Huntington's, Alzheimer's, and Pick's diseases. Exp Neurol 150:213-222

73. Smith R, Chung H, Rundquist S, Maat-Schieman ML, Colgan L, Englund E, Liu YJ, Roos RA, Faull RL, Brundin P, Li JY (2006) Cholinergic neuronal defect without cell loss in Huntington's disease. Hum Mol Genet 15:3119-3131

74. Snyder SW, Ladror US, Wade WS, Wang GT, Barrett LW, Matayoshi ED, Huffaker HJ, Krafft GA, Holzman TF (1994) Amyloid-beta aggregation: selective inhibition of aggregation in mixtures of amyloid with different chain lengths. Biophys J 67:1216-1228

75. Southwell AL, Smith SE, Davis TR, Caron NS, Villanueva EB, Xie Y, Collins JA, Ye ML, Sturrock A, Leavitt BR, Schrum AG, Hayden MR (2015) Ultrasensitive measurement of huntingtin protein in cerebrospinal fluid demonstrates increase with Huntington disease stage and decrease following brain huntingtin suppression. Sci Rep 5:12166

76. St-Amour I, Turgeon A, Goupil C, Planel E, Hébert SS (2018) Co-occurrence of mixed proteinopathies in late-stage Huntington's disease. Acta Neuropathol 135:249-265

77. Steffan JS, Kazantsev A, Spasic-Boskovic O, Greenwald M, Zhu YZ, Gohler H, Wanker EE, Bates GP, Housman DE, Thompson LM (2000) The Huntington's disease protein interacts with p53 and CREB-binding protein and represses transcription. Proc Natl Acad Sci U S A 97:6763-6768

78. Stiles L, Smith PF (2015) The vestibular-basal ganglia connection: balancing motor control. Brain Res 1597:180-188

79. Tsang EW, Hamani C, Moro E, Mazzella F, Poon YY, Lozano AM, Chen R (2010) Involvement of the human pedunculopontine nucleus region in voluntary movements. Neurology 75:950-959

80. Tsigelny IF, Crews L, Desplats P, Shaked GM, Sharikov Y, Mizuno H, Spencer B, Rockenstein E, Trejo M, Platoshyn O, Yuan JX, Masliah E (2008) Mechanisms of hybrid oligomer formation in the pathogenesis of combined Alzheimer's and Parkinson's diseases. PLoS One 3:e3135

81. Ueberham E, Böttger J, Ueberham U, Grosche J, Gebhardt R (2010) Response of sinusoidal mouse liver cells to choline-deficient ethioninesupplemented diet. Comp Hepatol 9:8

82. Velier J, Kim M, Schwarz C, Kim TW, Sapp E, Chase K, Aronin N, DiFiglia M (1998) Wild-type and mutant huntingtins function in vesicle trafficking in the secretory and endocytic pathways. Exp Neurol 152:34-40

83. Vonsattel JP (2008) Huntington disease models and human neuropathology: similarities and differences. Acta Neuropathol 115:55-69
84. Vonsattel JP, DiFiglia M (1998) Huntington disease. J Neuropathol Exp Neurol 57:369-384

85. Vonsattel JP, Myers RH, Stevens TJ, Ferrante RJ, Bird ED, Richardson EP Jr (1985) Neuropathological classification of Huntington's disease. J Neuropathol Exp Neurol 44:559-577

86. Walker FO (2007) Huntington's disease. Lancet 369:218-228

87. Wellington CL, Brinkman RR, O'Kusky JR, Hayden MR (1997) Toward understanding the molecular pathology of Huntington's disease. Brain Pathol 7:979-1002

88. Wood JD, MacMillan JC, Harper PS, Lowenstein PR, Jones AL (1996) Partial characterisation of murine huntingtin and apparent variations in the subcellular localisation of huntingtin in human, mouse and rat brain. Hum Mol Genet 5:481-487

89. Wood TE, Barry J, Yang Z, Cepeda C, Levine MS, Gray M (2019) Mutant huntingtin reduction in astrocytes slows disease progression in the BACHD conditional Huntington's disease mouse model. Hum Mol Genet 28:487-500

\section{Ready to submit your research? Choose BMC and benefit from:}

- fast, convenient online submission

- thorough peer review by experienced researchers in your field

- rapid publication on acceptance

- support for research data, including large and complex data types

- gold Open Access which fosters wider collaboration and increased citations

- maximum visibility for your research: over $100 \mathrm{M}$ website views per year

At $\mathrm{BMC}$, research is always in progress.

Learn more biomedcentral.com/submissions 